\title{
SAFETY IN RESIDENTIAL BUILDINGS - EVACUATION FROM RESIDENTIAL BUILDINGS WITHOUT FIRE ESCAPE STAIRS
}

\author{
Radoje B. Jevtić \\ Secondary School of Electrical Engineering "Nikola Tesla", \\ Niš, Republic of Serbia, \\ e-mail: milan.jvtc@gmail.com, \\ ORCID iD: (ibhttps://orcid.org/0000-0002-0179-1321
}

DOI: 10.5937/vojtehg69-28170; https://doi.org/10.5937/vojtehg69-28170

\author{
FIELD: Fire protection \\ ARTICLE TYPE: Original scientific paper
}

\begin{abstract}
:
Introduction/purpose: Safety in high residential buildings presents a very important and always actual task. In case of some unforeseen and dangerous occurrences, their residents must be evacuated. Fire, earthquakes, and terrorism are only some of such situations. The speed of evacuation from high residential buildings depends on many different factors. A particularly difficult and complex evacuation task concerns buildings without fire escape stairs.

Methods: The modeling method was used in this paper. Based on a real object - a residential building, an appropriate simulation model was realized in appropriate simulation software.

Results: The results of this paper have shown that, out of four scenarios, the fastest evacuation was for the evacuation speed of $1.75 \mathrm{~m} / \mathrm{s}$. The first two scenarios did not report any jams, unlike the third and fourth scenario; in the third scenario, the occupants' speeds were $0.75 \mathrm{~m} / \mathrm{s}$ and $1.25 \mathrm{~m} / \mathrm{s}$ while in the fourth scenario, the simulated occupants' speeds were from $0.75 \mathrm{~m} / \mathrm{s}$ to $1.75 \mathrm{~m} / \mathrm{s}$.

Conclusion:The usage of appropriate simulation software enables fast, precise, safe and cheap calculation of evacuation times and it can significantly improve evacuation procedures and evacuation strategies.
\end{abstract}

Key words: evacuation, building, human, simulation.

\section{Introduction}

An evacuation presents the most important measurement for population protection. This measurement generally comprises a planned and organized relocation of humans, animals, material properties, state 
authorities etc., from an endangered area to a safe area. Depending on a vulnerability degree and current damage, evacuation can be temporary or permanent. The reasons for evacuation can be different: fire, earthquake, floods, terrorism, nuclear disaster, tsunami, whirlwind, etc. Namely, it is important to note that there are differences between evacuation, displacement, and relocation of population.

Residential buildings present specific objects for evacuation, mostly because of a huge number of residents of different age. Besides this important factor, there are also other factors such as building construction and location, possibilities for fire fighters to approach the site, presence or absence of evacuation stairs, presence or absence of an escape rescue system, behavior of residents under stress, etc. For example, in the United States, in the period from 2007 to 2011, fire units had 15400 interventions because of fire in high buildings. These fires caused 46 victims, 530 civil injuries and more than 200 million dollars of damage, on the year level. It is interesting to note that $45 \%$ of all fires were caused in apartments; $3 \%$ of all fires were caused in hotels; $2 \%$ of all fires were caused in offices, and $1 \%$ of all fires was caused in elderly care objects (Mumović, 2019).

One very important event related to safety evacuation in high buildings was, unfortunately, the terrorist's attacks on the World Trade Centre in New York, on 11 September 2001. According to analyses, the evacuations of $87 \%$ of all occupants were realized in less than two hours. However, evacuation times were pretty different and complex to explain. Because of that reason, many different experts agreed that safety in high buildings would be much improved with a better understanding and analysis of human behavior in panic and stress situations. In addition, several very important factors influenced occupant behavior in general. Taking into account demographic characteristics, it was noted that $58 \%$ of all occupants were male with an average age of $44 ; 90 \%$ of all occupants were well educated, $56 \%$ of all occupants lived outside New York while $32 \%$ of all occupants lived in the neighborhood. Health and injury status of occupants were also important - it was noted that $23 \%$ of all occupants reported some medical problem. Familiarity with the building and installed fire safety measurements were very poor it was confirmed that only $20 \%$ of all occupants were introduced with proper actions after the alarm sounded (Gershon et al, 2011).

Regardless of building construction characteristics, evacuation from residential buildings can be realized in several ways: first, by stairs, and then by elevators or their combinations. Modern residential buildings built in recent times have several new and modern ways for evacuation, such 
as special security equipment, transport helicopters or some new construction solutions (connections between buildings or similar). In many cases, evacuation by stairs presents the only possible way for evacuation. Many high buildings have standard staircases and emergency stairs, many not. The realization of staircases demands detailed research about many factors, such as the position of the staircase, the material the stairs are made of, the staircase dimensions (width, riser and tread dimensions), stairs fire resistance, etc. (Pauls, 2005).

Although in the last twenty years fire protection systems and evacuation systems have significantly improved, accidents in high residential buildings have occurred. As an example, fires in residential buildings are presented in Figure 1 ( $a$ and $b$ ).

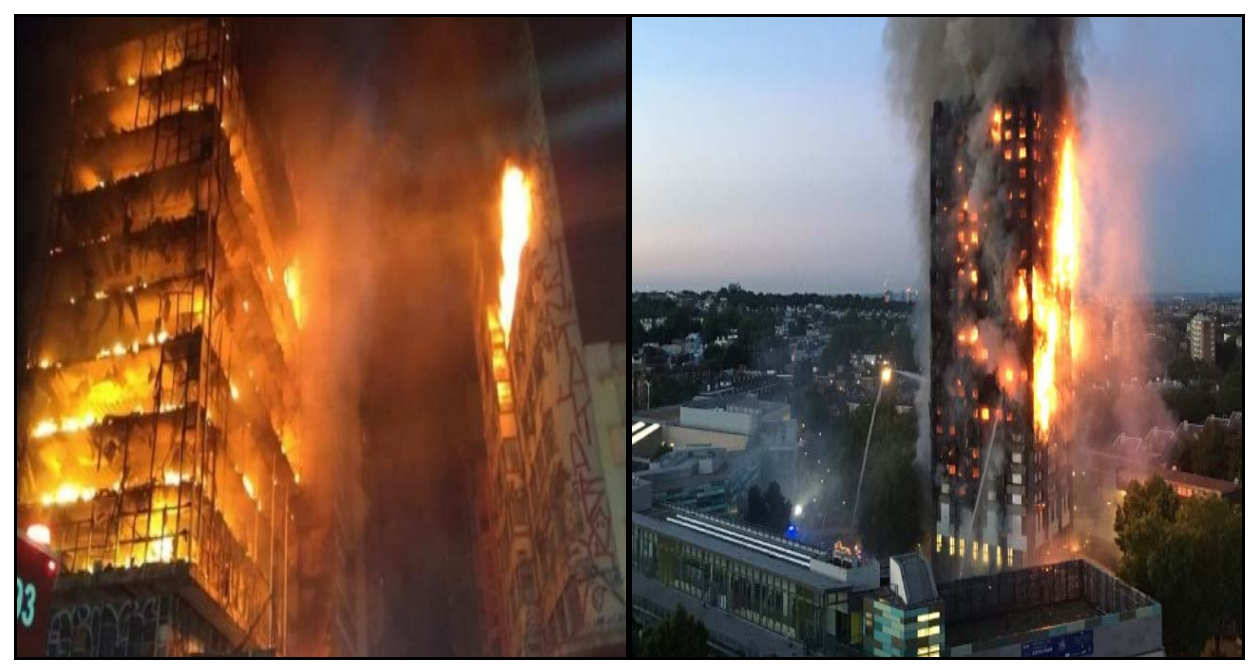

a)

b)

Figure 1 - Huge fire in a residential building in Sao Paolo, Brazil, in 2018 (a) (Fos Media, 2018) and a huge fire in the residential building Grenfell Tower in London, UK, in 2017 (b) (Hartley-Parkinson, 2019)

Puc. 1 - Крупный пожар в жилом здании в г.Сан-Паулу, Бразилия (а) (Fos Media, 2018) и крупный пожар в здании Гренфрелл-тауэр в Лондоне, ОК, 2017 (б) (HartleyParkinson, 2019)

Слика 1 - Велики пожар у стамбеној згради у Сао Паолу, Бразил, (а) (Fos Media, 2018) и велики пожар у стамбеној заради у Grenfell Tower-y у Лондону, УК, 2017(б) (Hartley-Parkinson, 2019)

The usage of elevators for evacuation is questionable for many different reasons: the lack of power supply, collapse capabilities, the 
possibilities of dangerous gases penetration (especially carbon monoxide $(\mathrm{CO})$ ), the lack of space, etc. Because of the noted reasons, many different evacuation approaches do not recommend elevators usage for evacuation (Glavinić \& Rasković, 2016).

The occupant behavior under stress and panic presents a very complex factor hard to define and predict. It is almost impossible to predict occupants' behavior in stress situations, no matter how educated or familiar with safety precautions they are. Occupants are, in normal conditions, aware and ready to find the best options, even in the cases when they should aid someone (help someone with disabilities, help children, etc.). However, are they able to do all this in the presence of smoke, flame, heat, crashes, explosions or other stress situations? A different age of occupants is also important and brings new moments of complexity and unpredictability (Ronchi \& Nilsson, 2013), (Jevtić, 2016).

It is obvious that successful evacuation in an accident, especially from a complex object such as a residential building, must be realized in the early stage of the accident. Of course, it implies the timely detection of an accident or a disaster. Because of that, it is important to predict, as closely as possible, all potential evacuation scenarios and situations. One of the best ways to predict evacuation situations and calculate time needed for evacuation is the usage of simulation software. The usage of simulation software and the analysis of potential evacuation scenarios for different evacuation factors present a new, effective, safe, and "all in" approach in building architecture. Powerful computers enable detailed analyses of evacuation by simulation and prediction of almost all potential scenarios. The given facts show that this topic has a great importance, primarily in the protection of human lives. On the other hand, a timely and well-planned evacuation enables a fast evacuation of occupants and a fast approach of fire fighters, which can significantly decrease damage to material properties. This paper was written to show the prediction of evacuation scenarios and the calculation of evacuation times in the case of a building without emergency stairs, using adequate simulation software.

\section{Pathfinder simulation software}

A successful and safely realized evacuation as well as saving lives and material properties can be significantly improved by using simulation software. The reasons for simulation software usage lie in the fact that such usage is, above all, safe and economically cost-effective. In addition, it has potentials to predict many different evacuation scenarios 
and calculations of evacuation times. There is a number of simulation software for evacuation on the market. One of them is Pathfinder. This simulation software is based on human movement. Until today, several different versions of this program have been developed. This powerful simulator enables a graphical user interface for simulation design and execution. It is possible to simulate human movements through objects, in elevators, on stairs, etc. The Pathfinder environment presents a 3D triangulated mesh designed to match the real dimensions of a building model. This software can support two different simulation ways: the steering mode and the SFPE mode. In addition, this software has a very important ability to import files from different programs such as FDS, 3D Cad and PyroSim, what enables much faster drawing of a simulation model and the usage of the existent simulation models with minor remakes. The Pathfinder version used for this paper was 2020 version (Thunderhead, 2014).

\section{Simulation model}

The object simulated in this paper was the building in the Bulevar Nemanjića Street, with numbers from 58 to 64 . This object actually presents four buildings connected in one. The object has four exits/entrances without emergency stairs. The main advantage of such objects is in their great stability in case of earthquakes. Every building has the basement, the ground floor, ten floors and a roof terrace. The buildings are connected via terraces. The connected terraces serve for evacuation in case that residents cannot get out through the entrance/exit.

Every building, taken separately, has two elevators, vault rooms, a loft and four flats on every floor started from the ground floor to the tenth floor. This means that every building, taken separately, has forty-four flats, i.e. there are one hundred and seventy six flats in total. There are two different flat types per floor, one with an approximate surface of 66 $\mathrm{m}^{2}$ and one with an approximate surface of $50 \mathrm{~m}^{2}$. Every building separately has two different elevators: one with a total capacity of four persons and one with a total capacity of six persons. The elevators have different speeds. These speeds were measured, and, for a smaller elevator type, the speed was $1.1 \mathrm{~m} / \mathrm{s}$, while the speed of a bigger elevator was $0.92 \mathrm{~m} / \mathrm{s}$. The maximum distance between the floors is approximately $2.6 \mathrm{~m}$, which means that the total height of the object is approximately $36-38 \mathrm{~m}$ (measured from the ground to the elevator machine room on the top of the building). Related to this object, a proper 
simulation model with all its real dimensions was constructed in Pathfinder software.

The positions of the residents were per floors and in flats, based on the resident lists. Because of visibility, the HIDE function from Pathfinder was used. This means that only some elements were visible, such as stairs, doors, elevators, etc. The total number of residents was 699, which was confirmed from the resident lists for every of four buildings separately (179 residents in the entrance/exit with number 58, 168 residents in the entrance/exit with number 60, 169 residents in the entrance/exit with number 62 , and 183 residents in the entrance/exit with number 64).

After the construction of the simulation model, it was decided to simulate four different scenarios. The first simulation scenario included all entrances/exits opened, with enabled and disabled elevators. The second simulation scenario included one entrance/exit blocked while other three entrances/exits were open (all potential 9 cases), with enabled and disabled elevators. The third simulation scenario included two entrances/exits blocked while other two entrances/exits were open (all potential 12 cases), with enabled and disabled elevators. The fourth simulation scenario was based on three entrances/exits blocked while one entrance/exit was open (all potential 8 cases), with enabled and disabled elevators. Each of four scenarios was realized for different speeds of occupants: $0.75 \mathrm{~m} / \mathrm{s}, 1 \mathrm{~m} / \mathrm{s}, 1.25 \mathrm{~m} / \mathrm{s}$, and $1.5 \mathrm{~m} / \mathrm{s}$ and 1.75 $\mathrm{m} / \mathrm{s}$ (Jevtić, 2018), (Jevtić, 2019a).

The residential building in Bulevar Nemanjića Street, from 58 to 64, Niš, is presented in Figure 2 (a), while the appropriate Pathfinder simulation model of the residential building in Bulevar Nemanjića Street is presented in Figure 2 (b).

\section{Simulation results}

The complete simulation results are presented from Table 1 to Table 30. The simulation results for the first scenario are presented in Tables 1 and 2. The simulation results for the second scenario are presented in Tables from 3 to 10 . The simulation results for the third scenario are presented in Tables from 11 to 22. The simulation results for the fourth scenario are presented in Tables from 23 to 30 . All simulations of the evacuation were realized on a laptop Honor MagicBook 15 with AMD Ryzen $53500 \mathrm{U}$ processor at $3.7 \mathrm{GHz}$ and $6 \mathrm{MB}$ of CASH memory and 8 GB DDR4 $2667 \mathrm{MHz}$. It is desirable to possess a strong hardware configuration for any kind of computer simulation. 


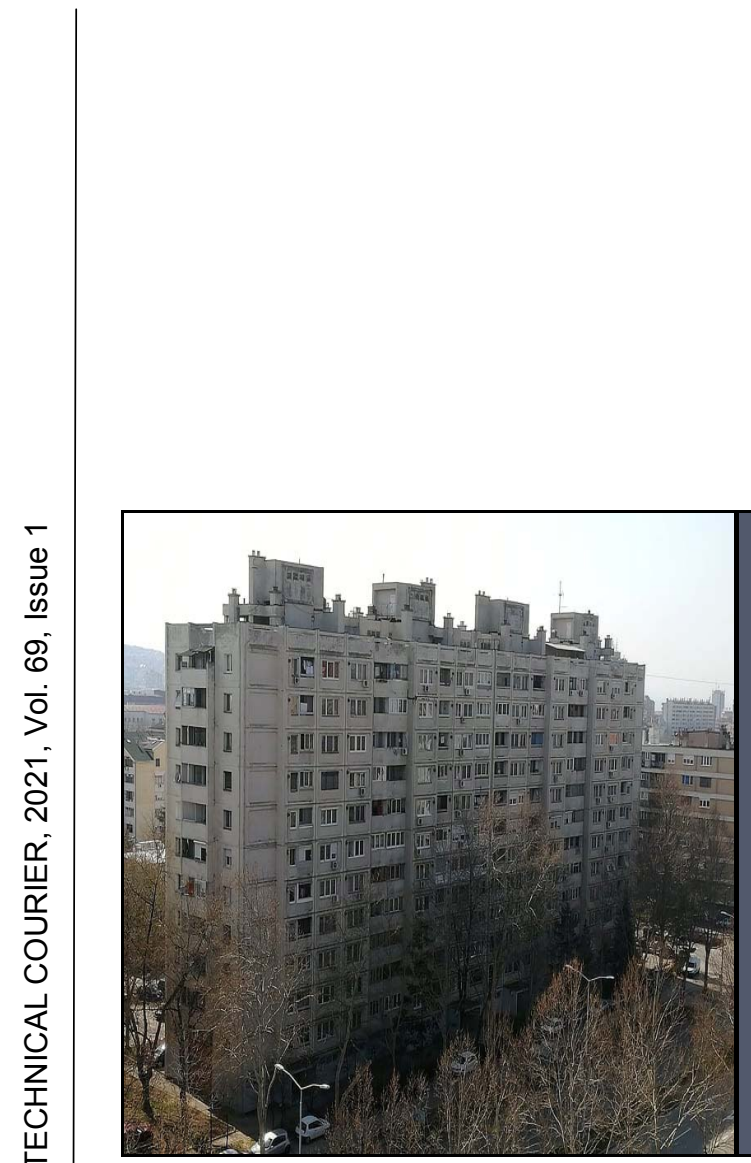

a)

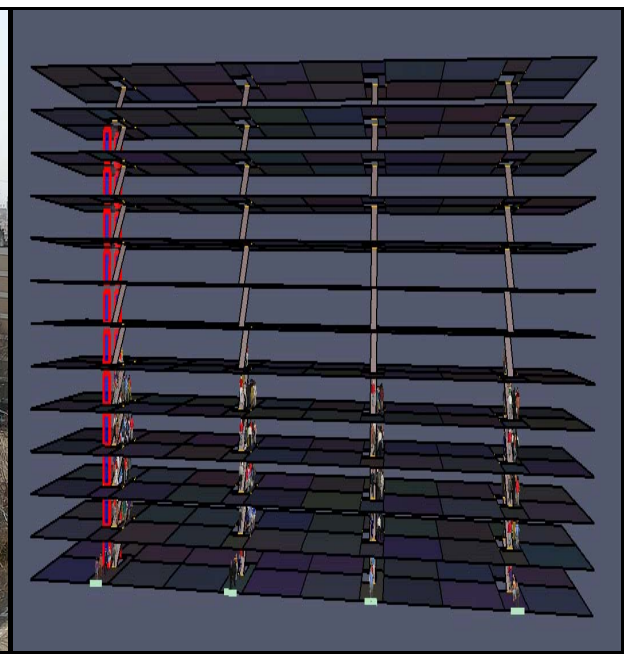

b)

Figure 2 - Building in Bulevar Nemanjića Street, from 58 to 64 (a) and the Pathfinder simulation model of the residential building in Bulevar Nemanjića Street (b)

Puc. 2 - Здание на Бульваре Неманича с 58 по 64 (a) и имитационная модель 8 жилом здании Pathfinder на Бульваре Неманича (б)

Слика 2 - Зграда у Булевару Немањића, од броја 58 до 64 (а), и симулациони модел у Pathfinder-у стамбене зграде у Булевару Немањића (б)

Table 1 - Simulation results in seconds for the first scenario, with elevators enabled and for the occupants' speeds from $0.75 \mathrm{~m} / \mathrm{s}, 1 \mathrm{~m} / \mathrm{s}, 1.25 \mathrm{~m} / \mathrm{s}, 1.5 \mathrm{~m} / \mathrm{s}$, and $1.75 \mathrm{~m} / \mathrm{s}$ Таблица 1 - Результаты симуляции, выраженные в секундах по первому сценарию, с лифртами, учитывая скорость жильцов: 0.75 м/с, 1 м/c, 1.25 м/c, 1.5 $\mathrm{M} / \mathrm{c} \cup 1.75 \mathrm{M} / \mathrm{C}$

Табела 1 - Симулациони резултати у секундама за први сценарио, са лифтовима и за брзине станара: 0,75 m/s, $1 \mathrm{~m} / \mathrm{s}, 1,25 \mathrm{~m} / \mathrm{s}, 1,5 \mathrm{~m} / \mathrm{s} \mathrm{u} \mathrm{1,75} \mathrm{m/s}$

\begin{tabular}{|l|c|c|c|c|c|c|c|}
\hline Number of occupants & 669 & 500 & 400 & 300 & 200 & 100 & 0 \\
\hline $\begin{array}{l}\text { Time for speed of } \\
\text { occupants } 0.75 \mathrm{~m} / \mathrm{s}\end{array}$ & 0 & 133 & 183 & 230 & 286 & 332 & 365 \\
\hline $\begin{array}{l}\text { Time for speed of } \\
\text { occupants } 1 \mathrm{~m} / \mathrm{s}\end{array}$ & 0 & 105.7 & 141.6 & 183.4 & 221 & 256 & 293 \\
\hline $\begin{array}{l}\text { Time for speed of } \\
\text { occupants } 1.25 \mathrm{~m} / \mathrm{s}\end{array}$ & 0 & 84 & 127 & 159 & 197 & 234 & 256 \\
\hline $\begin{array}{l}\text { Time for speed of } \\
\text { occupants } 1.5 \mathrm{~m} / \mathrm{s}\end{array}$ & 0 & 72.2 & 105.8 & 148 & 176 & 209 & 236 \\
\hline $\begin{array}{l}\text { Time for speed of } \\
\text { occupants } 1.75 \mathrm{~m} / \mathrm{s}\end{array}$ & 0 & 50 & 79 & 123 & 140 & 180 & 209 \\
\hline
\end{tabular}


Table 2 - Simulation results in seconds for the first scenario, with elevators disabled and for the occupants' speeds from $0.75 \mathrm{~m} / \mathrm{s}, 1 \mathrm{~m} / \mathrm{s}, 1.25 \mathrm{~m} / \mathrm{s}, 1.5 \mathrm{~m} / \mathrm{s}$, and $1.75 \mathrm{~m} / \mathrm{s}$ Таблица 2 - Результаты симуляции, выраженные в секундах по первому сценарию, без лифрта, учитывая скорость жильцов: 0.75 м/c, 1 м/c, 1.25 м/c, 1.5 $\mathrm{M} / \mathrm{c} \cup 1.75 \mathrm{M} / \mathrm{c}$

Табела 2 - Симулациони резултати у секундама за први сценарио, без лифтова и за брзине станара: $0,75 \mathrm{~m} / \mathrm{s}, 1 \mathrm{~m} / \mathrm{s}, 1,25 \mathrm{~m} / \mathrm{s}, 1,5 \mathrm{~m} / \mathrm{s}$ u 1,75 m/s

\begin{tabular}{|l|c|c|c|c|c|c|c|}
\hline Number of occupants & 669 & 500 & 400 & 300 & 200 & 100 & 0 \\
\hline $\begin{array}{l}\text { Time for speed of } \\
\text { occupants } 0.75 \mathrm{~m} / \mathrm{s}\end{array}$ & 0 & 145 & 203 & 255 & 313 & 351 & 442 \\
\hline $\begin{array}{l}\text { Time for speed of } \\
\text { occupants } 1 \mathrm{~m} / \mathrm{s}\end{array}$ & 0 & 123 & 177.6 & 219.4 & 257 & 292 & 334 \\
\hline $\begin{array}{l}\text { Time for speed of } \\
\text { occupants } 1.25 \mathrm{~m} / \mathrm{s}\end{array}$ & 0 & 113 & 156 & 188 & 226 & 263 & 288 \\
\hline $\begin{array}{l}\text { Time for speed of } \\
\text { occupants } 1.5 \mathrm{~m} / \mathrm{s}\end{array}$ & 0 & 95.2 & 128.8 & 171 & 199 & 232 & 267.6 \\
\hline $\begin{array}{l}\text { Time for speed of } \\
\text { occupants } 1.75 \mathrm{~m} / \mathrm{s}\end{array}$ & 0 & 74 & 88.7 & 133 & 150 & 187 & 232 \\
\hline
\end{tabular}

Table 3-Simulation results in seconds for the second scenario, with elevators enabled and the first entrance/exit blocked and for the occupants' speeds from $0.75 \mathrm{~m} / \mathrm{s}, 1 \mathrm{~m} / \mathrm{s}$, $1.25 \mathrm{~m} / \mathrm{s}, 1.5 \mathrm{~m} / \mathrm{s}$, and $1.75 \mathrm{~m} / \mathrm{s}$

Таблица 3 - Результаты симуляции, выраженные в секундах по второму сценарию, с лифртами и первым заблокированным входом/выходом, учитывая скорость жильцов: $0.75 \mathrm{M} / \mathrm{c}, 1 \mathrm{~m} / \mathrm{c}, 1.25 \mathrm{~m} / \mathrm{c}, 1.5 \mathrm{~m} / \mathrm{c}$ и $1.75 \mathrm{M} / \mathrm{c}$

Табела 3 - Симулациони резултати у секундама за други сценарио, са лифотовима и са првим блокираним улазом/излазом и за брзине станара: $0,75 \mathrm{~m} / \mathrm{s}$, $1 \mathrm{~m} / \mathrm{s}, 1,25 \mathrm{~m} / \mathrm{s}, 1,5 \mathrm{~m} / \mathrm{s}$ u $1,75 \mathrm{~m} / \mathrm{s}$

\begin{tabular}{|l|c|c|c|c|c|c|c|}
\hline Number of occupants & 669 & 500 & 400 & 300 & 200 & 100 & 0 \\
\hline $\begin{array}{l}\text { Time for speed of occupants } \\
0.75 \mathrm{~m} / \mathrm{s}\end{array}$ & 0 & 190 & 225 & 291 & 398 & 562 & 796 \\
\hline $\begin{array}{l}\text { Time for speed of occupants } \\
1 \mathrm{~m} / \mathrm{s}\end{array}$ & 0 & 160 & 195 & 254 & 342 & 501 & 627 \\
\hline $\begin{array}{l}\text { Time for speed of occupants } \\
1.25 \mathrm{~m} / \mathrm{s}\end{array}$ & 0 & 134 & 165 & 231 & 311 & 472 & 554 \\
\hline $\begin{array}{l}\text { Time for speed of occupants } \\
1.5 \mathrm{~m} / \mathrm{s}\end{array}$ & 0 & 118 & 136 & 201 & 284 & 420 & 499 \\
\hline $\begin{array}{l}\text { Time for speed of occupants } \\
1.75 \mathrm{~m} / \mathrm{s}\end{array}$ & 0 & 100 & 120 & 172 & 235 & 367 & 434 \\
\hline
\end{tabular}


Table 4 - Simulation results in seconds for the second scenario, with elevators enabled and the second entrance/exit blocked and for the occupants' speeds from $0.75 \mathrm{~m} / \mathrm{s}, 1$ $\mathrm{m} / \mathrm{s}, 1.25 \mathrm{~m} / \mathrm{s}, 1.5 \mathrm{~m} / \mathrm{s}$, and $1.75 \mathrm{~m} / \mathrm{s}$

Таблица 4 - Результаты симуляции, выраженные в секундах по второму сценарию, с лифртами и вторым заблокированным входом/выходом, учитывая скорость жильцов: $0.75 \mathrm{M} / \mathrm{c}, 1 \mathrm{M} / \mathrm{c}, 1.25 \mathrm{M} / \mathrm{c}, 1.5 \mathrm{M} / \mathrm{c} u 1.75 \mathrm{M} / \mathrm{c}$

Табела 4 - Симулациони резултати у секундама за други сценарио, са лифртовима и са другим блокираним улазом/излазом, и за брзине станара: 0,75 $\mathrm{m} / \mathrm{s}, 1 \mathrm{~m} / \mathrm{s}, 1,25 \mathrm{~m} / \mathrm{s}, 1,5 \mathrm{~m} / \mathrm{s}$ u $1,75 \mathrm{~m} / \mathrm{s}$

\begin{tabular}{|l|c|c|c|c|c|c|c|}
\hline Number of occupants & 669 & 500 & 400 & 300 & 200 & 100 & 0 \\
\hline $\begin{array}{l}\text { Time for speed of occupants } \\
0.75 \mathrm{~m} / \mathrm{s}\end{array}$ & 0 & 184 & 213 & 275 & 380 & 546 & 772 \\
\hline $\begin{array}{l}\text { Time for speed of occupants } \\
1 \mathrm{~m} / \mathrm{s}\end{array}$ & 0 & 155 & 184 & 239 & 320 & 487 & 600 \\
\hline $\begin{array}{l}\text { Time for speed of occupants } \\
1.25 \mathrm{~m} / \mathrm{s}\end{array}$ & 0 & 128 & 155 & 218 & 295 & 455 & 530 \\
\hline $\begin{array}{l}\text { Time for speed of occupants } \\
1.5 \mathrm{~m} / \mathrm{s}\end{array}$ & 0 & 113 & 126 & 190 & 266 & 406 & 468 \\
\hline $\begin{array}{l}\text { Time for speed of occupants } \\
1.75 \mathrm{~m} / \mathrm{s}\end{array}$ & 0 & 95 & 110 & 166.4 & 221 & 351 & 422 \\
\hline
\end{tabular}

Table 5 - Simulation results in seconds for the second scenario, with elevators enabled and the third entrance/exit blocked and for the occupants' speeds from $0.75 \mathrm{~m} / \mathrm{s}, 1 \mathrm{~m} / \mathrm{s}$, $1.25 \mathrm{~m} / \mathrm{s}, 1.5 \mathrm{~m} / \mathrm{s}$, and $1.75 \mathrm{~m} / \mathrm{s}$

Таблица 5 - Результаты симуляции, выраженные в секундах по второму сценарию, с лифртами и третьим заблокированным входом/выходом, учитывая скорость жильцов: $0.75 \mathrm{M} / \mathrm{c}, 1 \mathrm{M} / \mathrm{c}, 1.25 \mathrm{M} / \mathrm{c}, 1.5 \mathrm{M} / \mathrm{c}$ и $1.75 \mathrm{M} / \mathrm{c}$

Табела 5 - Симулациони резултати у секундама за други сценарио, са лифртовима и са трећим блокираним улазом/излазом, и за брзине станара: 0,75 $\mathrm{m} / \mathrm{s}, 1 \mathrm{~m} / \mathrm{s}, 1,25 \mathrm{~m} / \mathrm{s}, 1,5 \mathrm{~m} / \mathrm{s}$ u $1,75 \mathrm{~m} / \mathrm{s}$

\begin{tabular}{|l|c|c|c|c|c|c|c|}
\hline Number of occupants & 669 & 500 & 400 & 300 & 200 & 100 & 0 \\
\hline $\begin{array}{l}\text { Time for speed of occupants } \\
0.75 \mathrm{~m} / \mathrm{s}\end{array}$ & 0 & 199 & 225 & 290 & 397 & 566 & 789 \\
\hline $\begin{array}{l}\text { Time for speed of occupants } \\
1 \mathrm{~m} / \mathrm{s}\end{array}$ & 0 & 167 & 199 & 253 & 336 & 506 & 615 \\
\hline $\begin{array}{l}\text { Time for speed of occupants } \\
1.25 \mathrm{~m} / \mathrm{s}\end{array}$ & 0 & 136 & 174 & 234 & 311 & 475 & 543 \\
\hline $\begin{array}{l}\text { Time for speed of occupants } \\
1.5 \mathrm{~m} / \mathrm{s}\end{array}$ & 0 & 122 & 150 & 202 & 280 & 422 & 480 \\
\hline $\begin{array}{l}\text { Time for speed of occupants } \\
1.75 \mathrm{~m} / \mathrm{s}\end{array}$ & 0 & 104 & 132 & 180 & 235 & 369 & 432 \\
\hline
\end{tabular}


Table 6 - Simulation results in seconds for the second scenario, with elevators enabled and the fourth entrance/exit blocked and for the occupants' speeds from $0.75 \mathrm{~m} / \mathrm{s}, 1 \mathrm{~m} / \mathrm{s}$, $1.25 \mathrm{~m} / \mathrm{s}, 1.5 \mathrm{~m} / \mathrm{s}$, and $1.75 \mathrm{~m} / \mathrm{s}$

Таблица 6 - Результаты симуляции, выраженные в секундах по второму сценарию, с лифртами и четвертым заблокированным входом/выходом, учитывая скорость жильцов: $0.75 \mathrm{M} / \mathrm{c}, 1 \mathrm{M} / \mathrm{c}, 1.25 \mathrm{M} / \mathrm{c}, 1.5 \mathrm{M} / \mathrm{c}$ и $1.75 \mathrm{M} / \mathrm{c}$

Табела 6 - Симулациони резултати у секундама за други сценарио, са лифттовима и са четвртим блокираним улазом/излазом, и за брзине станара: $0,75 \mathrm{~m} / \mathrm{s}, 1 \mathrm{~m} / \mathrm{s}, 1,25 \mathrm{~m} / \mathrm{s}, 1,5 \mathrm{~m} / \mathrm{s}$ u $1,75 \mathrm{~m} / \mathrm{s}$

\begin{tabular}{|l|c|c|c|c|c|c|c|}
\hline Number of occupants & 669 & 500 & 400 & 300 & 200 & 100 & 0 \\
\hline $\begin{array}{l}\text { Time for speed of occupants } \\
0.75 \mathrm{~m} / \mathrm{s}\end{array}$ & 0 & 210 & 239 & 306 & 415 & 588 & 811 \\
\hline $\begin{array}{l}\text { Time for speed of occupants } \\
1 \mathrm{~m} / \mathrm{s}\end{array}$ & 0 & 178 & 213 & 269 & 354 & 526 & 639 \\
\hline $\begin{array}{l}\text { Time for speed of occupants } \\
1.25 \mathrm{~m} / \mathrm{s}\end{array}$ & 0 & 147 & 185 & 250 & 330 & 496 & 566 \\
\hline $\begin{array}{l}\text { Time for speed of occupants } \\
1.5 \mathrm{~m} / \mathrm{s}\end{array}$ & 0 & 135 & 164 & 217 & 297 & 444 & 503 \\
\hline $\begin{array}{l}\text { Time for speed of occupants } \\
1.75 \mathrm{~m} / \mathrm{s}\end{array}$ & 0 & 116 & 144 & 194 & 253 & 390 & 457 \\
\hline
\end{tabular}

Table 7 - Simulation results in seconds for the second scenario, with elevators disabled and the first entrance/exit blocked and for the occupants' speeds from $0.75 \mathrm{~m} / \mathrm{s}, 1 \mathrm{~m} / \mathrm{s}$, $1.25 \mathrm{~m} / \mathrm{s}, 1.5 \mathrm{~m} / \mathrm{s}$, and $1.75 \mathrm{~m} / \mathrm{s}$

Таблица 7 - Результаты симуляции, выраженные в секундах по второму сценарию, без лифта и с первым заблокированным входом/выходом, учитывая скорость жильцов: $0.75 \mathrm{~m} / \mathrm{c}, 1 \mathrm{M} / \mathrm{c}, 1.25 \mathrm{M} / \mathrm{c}, 1.5 \mathrm{M} / \mathrm{c}$ и $1.75 \mathrm{M} / \mathrm{c}$

Табела 7 - Симулациони резултати у секундама за други сценарио, без лифтова и са првим блокираним улазом/излазом, и за брзине станара: 0,75 m/s, $1 \mathrm{~m} / \mathrm{s}, 1,25$ $\mathrm{m} / \mathrm{s}, 1,5 \mathrm{~m} / \mathrm{s}$ u $1,75 \mathrm{~m} / \mathrm{s}$

\begin{tabular}{|l|c|c|c|c|c|c|c|}
\hline Number of occupants & 669 & 500 & 400 & 300 & 200 & 100 & 0 \\
\hline $\begin{array}{l}\text { Time for speed of } \\
\text { occupants } 0.75 \mathrm{~m} / \mathrm{s}\end{array}$ & 0 & 270 & 306 & 372 & 480 & 642 & 873 \\
\hline $\begin{array}{l}\text { Time for speed of } \\
\text { occupants } 1 \mathrm{~m} / \mathrm{s}\end{array}$ & 0 & 240 & 278 & 337 & 420 & 582 & 700 \\
\hline $\begin{array}{l}\text { Time for speed of } \\
\text { occupants } 1.25 \mathrm{~m} / \mathrm{s}\end{array}$ & 0 & 215 & 248 & 315 & 390 & 553 & 634.9 \\
\hline $\begin{array}{l}\text { Time for speed of } \\
\text { occupants } 1.5 \mathrm{~m} / \mathrm{s}\end{array}$ & 0 & 199 & 217 & 281.3 & 363 & 499 & 579.5 \\
\hline $\begin{array}{l}\text { Time for speed of } \\
\text { occupants } 1.75 \mathrm{~m} / \mathrm{s}\end{array}$ & 0 & 181 & 200 & 250 & 313 & 447 & 515 \\
\hline
\end{tabular}


Table 8 - Simulation results in seconds for the second scenario, with elevators disabled and the second entrance/exit blocked and for the occupants' speeds from $0.75 \mathrm{~m} / \mathrm{s}, 1$ $\mathrm{m} / \mathrm{s}, 1.25 \mathrm{~m} / \mathrm{s}, 1.5 \mathrm{~m} / \mathrm{s}$, and $1.75 \mathrm{~m} / \mathrm{s}$

Таблица 8 - Результаты симуляции, выраженные в секундах по второму сценарию, без лифрта и со вторым заблокированным входом/выходом, учитывая скорость жильцов: $0.75 \mathrm{M} / \mathrm{c}, 1 \mathrm{M} / \mathrm{c}, 1.25 \mathrm{M} / \mathrm{c}, 1.5 \mathrm{M} / \mathrm{c}$ и $1.75 \mathrm{M} / \mathrm{c}$

Табела 8 - Симулациони резултати у секундама за други сценарио, без лифтоова и са другим блокираним улазом/излазом, и за брзине станара: 0,75 m/s, $1 \mathrm{~m} / \mathrm{s}, 1,25$ $\mathrm{m} / \mathrm{s}, 1,5 \mathrm{~m} / \mathrm{s}$ u $1,75 \mathrm{~m} / \mathrm{s}$

\begin{tabular}{|l|c|c|c|c|c|c|c|}
\hline Number of occupants & 669 & 500 & 400 & 300 & 200 & 100 & 0 \\
\hline $\begin{array}{l}\text { Time for speed of } \\
\text { occupants } 0.75 \mathrm{~m} / \mathrm{s}\end{array}$ & 0 & 220 & 250 & 313.6 & 418.4 & 580 & 812 \\
\hline $\begin{array}{l}\text { Time for speed of } \\
\text { occupants } 1 \mathrm{~m} / \mathrm{s}\end{array}$ & 0 & 193.4 & 223 & 280.9 & 361.6 & 528.2 & 642 \\
\hline $\begin{array}{l}\text { Time for speed of } \\
\text { occupants } 1.25 \mathrm{~m} / \mathrm{s}\end{array}$ & 0 & 162 & 192 & 260 & 330 & 493 & 569 \\
\hline $\begin{array}{l}\text { Time for speed of } \\
\text { occupants } 1.5 \mathrm{~m} / \mathrm{s}\end{array}$ & 0 & 152 & 168 & 229.5 & 302 & 443 & 525 \\
\hline $\begin{array}{l}\text { Time for speed of } \\
\text { occupants } 1.75 \mathrm{~m} / \mathrm{s}\end{array}$ & 0 & 133.7 & 149 & 205.3 & 260 & 390.4 & 460 \\
\hline
\end{tabular}

Table 9 - Simulation results in seconds for the second scenario, with elevators disabled and the third entrance/exit blocked and for the occupants' speeds from $0.75 \mathrm{~m} / \mathrm{s}, 1 \mathrm{~m} / \mathrm{s}$, $1.25 \mathrm{~m} / \mathrm{s}, 1.5 \mathrm{~m} / \mathrm{s}$, and $1.75 \mathrm{~m} / \mathrm{s}$

Таблица 9 - Результаты симуляции, выраженные в секундах по второму сценарию, без лифтта и с третьим заблокированным входом/выходом, учитывая скорость жильцов: $0.75 \mathrm{M} / \mathrm{c}, 1 \mathrm{M} / \mathrm{c}, 1.25 \mathrm{M} / \mathrm{c}, 1.5 \mathrm{M} / \mathrm{c} \mathrm{u} 1.75 \mathrm{M} / \mathrm{c}$

Табела 9 - Симулациони резултати у секундама за други сценарио, без лифтова и са трећим блокираним улазом/излазом, и за брзине станара: 0,75 m/s, $1 \mathrm{~m} / \mathrm{s}$,

\begin{tabular}{|l|c|c|c|c|c|c|c|}
\hline Number of occupants & 669 & 500 & 400 & 300 & 200 & 100 & 0 \\
\hline $\begin{array}{l}\text { Time for speed of } \\
\text { occupants 0.75 m/s }\end{array}$ & 0 & 264.4 & 295 & 357.4 & 462 & 620 & 856 \\
\hline $\begin{array}{l}\text { Time for speed of } \\
\text { occupants 1 m/s }\end{array}$ & 0 & 237.6 & 267.6 & 324.4 & 402 & 567 & 684 \\
\hline $\begin{array}{l}\text { Time for speed of } \\
\text { occupants } 1.25 \mathrm{~m} / \mathrm{s}\end{array}$ & 0 & 206.6 & 237.6 & 303 & 370.4 & 537 & 613 \\
\hline $\begin{array}{l}\text { Time for speed of } \\
\text { occupants } 1.5 \mathrm{~m} / \mathrm{s}\end{array}$ & 0 & 197.4 & 224.6 & 276.4 & 345 & 481 & 569 \\
\hline $\begin{array}{l}\text { Time for speed of } \\
\text { occupants } 1.75 \mathrm{~m} / \mathrm{s}\end{array}$ & 0 & 149 & 198.5 & 248.6 & 305 & 434 & 503.5 \\
\hline
\end{tabular}


Table 10 - Simulation results in seconds for the second scenario, with elevators disabled and the fourth entrance/exit blocked and for the occupants' speeds from $0.75 \mathrm{~m} / \mathrm{s}, 1 \mathrm{~m} / \mathrm{s}$, $1.25 \mathrm{~m} / \mathrm{s}, 1.5 \mathrm{~m} / \mathrm{s}$, and $1.75 \mathrm{~m} / \mathrm{s}$

Таблица 10 - Результаты симуляции, выраженные в секундах по второму сценарию, без лифта и с четвертым заблокированным входом/выходом, учитывая скорость жильцов: $0.75 \mathrm{M} / \mathrm{c}, 1 \mathrm{M} / \mathrm{c}, 1.25 \mathrm{M} / \mathrm{c}, 1.5 \mathrm{M} / \mathrm{c}$ и $1.75 \mathrm{M} / \mathrm{c}$

Табела 10 - Симулациони резултати у секундама за други сценарио, без лифртова и са четвртим блокираним улазом/излазом, и за брзине станара: 0,75 $\mathrm{m} / \mathrm{s}, 1 \mathrm{~m} / \mathrm{s}, 1,25 \mathrm{~m} / \mathrm{s}, 1,5 \mathrm{~m} / \mathrm{s}$ и $1,75 \mathrm{~m} / \mathrm{s}$

\begin{tabular}{|l|c|c|c|c|c|c|c|}
\hline Number of occupants & 669 & 500 & 400 & 300 & 200 & 100 & 0 \\
\hline $\begin{array}{l}\text { Time for speed of } \\
\text { occupants } 0.75 \mathrm{~m} / \mathrm{s}\end{array}$ & 0 & 292 & 330 & 393 & 494 & 657 & 893 \\
\hline $\begin{array}{l}\text { Time for speed of } \\
\text { occupants } 1 \mathrm{~m} / \mathrm{s}\end{array}$ & 0 & 274 & 304 & 361 & 439 & 603 & 720.2 \\
\hline $\begin{array}{l}\text { Time for speed of } \\
\text { occupants } 1.25 \mathrm{~m} / \mathrm{s}\end{array}$ & 0 & 243 & 273 & 340 & 405.3 & 573.5 & 649 \\
\hline $\begin{array}{l}\text { Time for speed of } \\
\text { occupants } 1.5 \mathrm{~m} / \mathrm{s}\end{array}$ & 0 & 214 & 258 & 314.4 & 382 & 525.6 & 606 \\
\hline $\begin{array}{l}\text { Time for speed of } \\
\text { occupants } 1.75 \mathrm{~m} / \mathrm{s}\end{array}$ & 0 & 195 & 234 & 284.4 & 341 & 471.5 & 541.5 \\
\hline
\end{tabular}

Table 11 - Simulation results in seconds for the third scenario, with elevators enabled and the first and the second entrances/exits blocked and for the occupants' speeds from $0.75 \mathrm{~m} / \mathrm{s}, 1 \mathrm{~m} / \mathrm{s}, 1.25 \mathrm{~m} / \mathrm{s}, 1.5 \mathrm{~m} / \mathrm{s}$, and $1.75 \mathrm{~m} / \mathrm{s}$

Таблица 11 - Результаты симуляции, выраженные в секундах по третьему сценарию, с лисртами и с первым и вторым заблокированными входами/выходами, учитывая скорость жильцов: $0.75 \mathrm{M} / \mathrm{c}, 1 \mathrm{M} / \mathrm{c}, 1.25 \mathrm{M} / \mathrm{c}, 1.5 \mathrm{M} / \mathrm{c} \mathrm{u}$ $1.75 \mathrm{M} / \mathrm{C}$

Табела 11 - Симулациони резултати у секундама за трећи сценарио, са лифотовима и са првим и другим блокираним улазима/излазима , и за брзине станара: $0,75 \mathrm{~m} / \mathrm{s}, 1 \mathrm{~m} / \mathrm{s}, 1,25 \mathrm{~m} / \mathrm{s}, 1,5 \mathrm{~m} / \mathrm{s} \mathrm{u} 1,75 \mathrm{~m} / \mathrm{s}$

\begin{tabular}{|l|c|c|c|c|c|c|c|}
\hline Number of occupants & 669 & 500 & 400 & 300 & 200 & 100 & 0 \\
\hline $\begin{array}{l}\text { Time for speed of } \\
\text { occupants 0.75 m/s }\end{array}$ & 0 & 314 & 357 & 416 & 517 & 679 & 915 \\
\hline $\begin{array}{l}\text { Time for speed of } \\
\text { occupants 1 m/s }\end{array}$ & 0 & 296 & 325 & 384 & 460 & 624 & 742 \\
\hline $\begin{array}{l}\text { Time for speed of } \\
\text { occupants 1.25 m/s }\end{array}$ & 0 & 264 & 294.6 & 360.9 & 426.7 & 595.2 & 671 \\
\hline $\begin{array}{l}\text { Time for speed of } \\
\text { occupants 1.5 m/s }\end{array}$ & 0 & 235.2 & 278.7 & 336 & 402 & 547.7 & 627 \\
\hline $\begin{array}{l}\text { Time for speed of } \\
\text { occupants 1.75 m/s }\end{array}$ & 0 & 216 & 254 & 304 & 361 & 494 & 565 \\
\hline
\end{tabular}


Table 12 - Simulation results in seconds for the third scenario, with elevators enabled and the first and the third entrances/exits blocked and for the occupants' speeds from $0.75 \mathrm{~m} / \mathrm{s}, 1 \mathrm{~m} / \mathrm{s}, 1.25 \mathrm{~m} / \mathrm{s}, 1.5 \mathrm{~m} / \mathrm{s}$, and $1.75 \mathrm{~m} / \mathrm{s}$

Таблица 12 - Результаты симуляции, выраженные в секундах по третьему сценарию, с лифртами и с первым и третьим заблокированными входами/выходами, учитывая скорость жильцов: $0.75 \mathrm{M} / \mathrm{c}, 1 \mathrm{M} / \mathrm{c}, 1.25 \mathrm{M} / \mathrm{c}, 1.5 \mathrm{M} / \mathrm{c}$ и $1.75 \mathrm{M} / \mathrm{c}$

Табела 12 - Симулациони резултати у секундама за трећи сценарио, са лифотовима и са првим и трећим блокираним улазима/излазима, и за брзине станара: $0,75 \mathrm{~m} / \mathrm{s}, 1 \mathrm{~m} / \mathrm{s}, 1,25 \mathrm{~m} / \mathrm{s}, 1,5 \mathrm{~m} / \mathrm{s}$ и $1,75 \mathrm{~m} / \mathrm{s}$

\begin{tabular}{|l|c|c|c|c|c|c|c|}
\hline Number of occupants & 669 & 500 & 400 & 300 & 200 & 100 & 0 \\
\hline $\begin{array}{l}\text { Time for speed of } \\
\text { occupants } 0.75 \mathrm{~m} / \mathrm{s}\end{array}$ & 0 & 326 & 369 & 428 & 529 & 691 & 927 \\
\hline $\begin{array}{l}\text { Time for speed of } \\
\text { occupants } 1 \mathrm{~m} / \mathrm{s}\end{array}$ & 0 & 308 & 337 & 396 & 472 & 636 & 754 \\
\hline $\begin{array}{l}\text { Time for speed of } \\
\text { occupants } 1.25 \mathrm{~m} / \mathrm{s}\end{array}$ & 0 & 276 & 306.6 & 373.4 & 439 & 607.2 & 683 \\
\hline $\begin{array}{l}\text { Time for speed of } \\
\text { occupants } 1.5 \mathrm{~m} / \mathrm{s}\end{array}$ & 0 & 248 & 290.7 & 348 & 414 & 560.2 & 639 \\
\hline $\begin{array}{l}\text { Time for speed of } \\
\text { occupants } 1.75 \mathrm{~m} / \mathrm{s}\end{array}$ & 0 & 228 & 266 & 316 & 373 & 506 & 577 \\
\hline
\end{tabular}

Table 13 - Simulation results in seconds for the third scenario, with elevators enabled and the first and the fourth entrances/exits blocked and for the occupants' speeds from $0.75 \mathrm{~m} / \mathrm{s}, 1 \mathrm{~m} / \mathrm{s}, 1.25 \mathrm{~m} / \mathrm{s}, 1.5 \mathrm{~m} / \mathrm{s}$, and $1.75 \mathrm{~m} / \mathrm{s}$

Таблица 13 - Результаты симуляции, выраженные в секундах по третьему сценарию, с лифтами и с первым и четвертым заблокированными входами/выходами, учитывая скорость жильцов: $0.75 \mathrm{M} / \mathrm{c}, 1 \mathrm{M} / \mathrm{c}, 1.25 \mathrm{M} / \mathrm{c}, 1.5 \mathrm{M} / \mathrm{c} \mathrm{u}$ $1.75 \mathrm{M} / \mathrm{c}$

Табела 13 - Симулациони резултати у секундама за трећи сценарио, са лифртовима и са првим и четвртим блокираним улазима/излазима, и за брзине станара: 0,75 m/s, $1 \mathrm{~m} / \mathrm{s}, 1,25 \mathrm{~m} / \mathrm{s}, 1,5 \mathrm{~m} / \mathrm{s}$ u $1,75 \mathrm{~m} / \mathrm{s}$

\begin{tabular}{|l|c|c|c|c|c|c|c|}
\hline Number of occupants & 669 & 500 & 400 & 300 & 200 & 100 & 0 \\
\hline $\begin{array}{l}\text { Time for speed of } \\
\text { occupants 0.75 m/s }\end{array}$ & 0 & 353 & 397 & 453 & 558.4 & 718.3 & 952.9 \\
\hline $\begin{array}{l}\text { Time for speed of } \\
\text { occupants 1 m/s }\end{array}$ & 0 & 334.4 & 364 & 423 & 500 & 661.6 & 782.1 \\
\hline $\begin{array}{l}\text { Time for speed of } \\
\text { occupants 1.25 m/s }\end{array}$ & 0 & 304 & 331 & 401.8 & 465 & 635.6 & 709 \\
\hline $\begin{array}{l}\text { Time for speed of } \\
\text { occupants 1.5 m/s }\end{array}$ & 0 & 274 & 318.3 & 374 & 440 & 591 & 665 \\
\hline $\begin{array}{l}\text { Time for speed of } \\
\text { occupants } 1.75 \mathrm{~m} / \mathrm{s}\end{array}$ & 0 & 254.7 & 292 & 342 & 400.5 & 532 & 605 \\
\hline
\end{tabular}


Table 14 - Simulation results in seconds for the third scenario, with elevators enabled and the second and the third entrances/exits blocked and for the occupants' speeds from $0.75 \mathrm{~m} / \mathrm{s}, 1 \mathrm{~m} / \mathrm{s}, 1.25 \mathrm{~m} / \mathrm{s}, 1.5 \mathrm{~m} / \mathrm{s}$, and $1.75 \mathrm{~m} / \mathrm{s}$

Таблица 14 - Результаты симуляции, выраженные в секундах по третьему сценарию, с лифттами и со вторым и третьим заблокированными входами/выходами, учитывая скорость жильцов: $0.75 \mathrm{M} / \mathrm{c}, 1 \mathrm{M} / \mathrm{c}, 1.25 \mathrm{~m} / \mathrm{c}, 1.5 \mathrm{M} / \mathrm{c} \mathrm{u}$ $1.75 \mathrm{M} / \mathrm{C}$

Табела 14 - Симулациони резултати у секундама за трећи сценарио, са лифтовима и са другим и трећим блокираним улазима/излазима, и за брзине станара: $0,75 \mathrm{~m} / \mathrm{s}, 1 \mathrm{~m} / \mathrm{s}, 1,25 \mathrm{~m} / \mathrm{s}, 1,5 \mathrm{~m} / \mathrm{s}$ и $1,75 \mathrm{~m} / \mathrm{s}$

\begin{tabular}{|l|c|c|c|c|c|c|c|}
\hline Number of occupants & 669 & 500 & 400 & 300 & 200 & 100 & 0 \\
\hline $\begin{array}{l}\text { Time for speed of } \\
\text { occupants 0.75 m/s }\end{array}$ & 0 & 298 & 340 & 400 & 500 & 663 & 899 \\
\hline $\begin{array}{l}\text { Time for speed of } \\
\text { occupants 1 m/s }\end{array}$ & 0 & 281 & 310 & 369 & 445 & 609 & 727 \\
\hline $\begin{array}{l}\text { Time for speed of } \\
\text { occupants } 1.25 \mathrm{~m} / \mathrm{s}\end{array}$ & 0 & 249 & 279.6 & 345.9 & 411.7 & 579.8 & 656 \\
\hline $\begin{array}{l}\text { Time for speed of } \\
\text { occupants } 1.5 \mathrm{~m} / \mathrm{s}\end{array}$ & 0 & 220.2 & 263.7 & 320.5 & 387 & 531.2 & 612 \\
\hline $\begin{array}{l}\text { Time for speed of } \\
\text { occupants } 1.75 \mathrm{~m} / \mathrm{s}\end{array}$ & 0 & 201 & 240.4 & 290.2 & 345.5 & 479 & 550 \\
\hline
\end{tabular}

Table 15 - Simulation results in seconds for the third scenario, with elevators enabled and the second and the fourth entrances/exits blocked and for the occupants' speeds from $0.75 \mathrm{~m} / \mathrm{s}, 1 \mathrm{~m} / \mathrm{s}, 1.25 \mathrm{~m} / \mathrm{s}, 1.5 \mathrm{~m} / \mathrm{s}$, and $1.75 \mathrm{~m} / \mathrm{s}$

Таблица 15 - Результаты симуляции, выраженные в секундах по третьему сценарию,

с лифттами и со вторым и четвертым заблокированными входами/выходами, учитывая скорость жильцов: $0.75 \mathrm{~m} / \mathrm{c}, 1 \mathrm{M} / \mathrm{c}, 1.25 \mathrm{M} / \mathrm{c}, 1.5 \mathrm{~m} / \mathrm{c}$ и $1.75 \mathrm{M} / \mathrm{c}$

Табела 15 - Симулациони резултати у секундама за трећи сценарио, са лифртовима и са другим и четвртим блокираним улазима/излазима, и за брзине станара: $0,75 \mathrm{~m} / \mathrm{s}, 1 \mathrm{~m} / \mathrm{s}, 1,25 \mathrm{~m} / \mathrm{s}, 1,5 \mathrm{~m} / \mathrm{s}$ u $1,75 \mathrm{~m} / \mathrm{s}$

\begin{tabular}{|l|c|c|c|c|c|c|c|}
\hline Number of occupants & 669 & 500 & 400 & 300 & 200 & 100 & 0 \\
\hline $\begin{array}{l}\text { Time for speed of } \\
\text { occupants 0.75 m/s }\end{array}$ & 0 & 337 & 380 & 439 & 541.5 & 702 & 938 \\
\hline $\begin{array}{l}\text { Time for speed of } \\
\text { occupants 1 m/s }\end{array}$ & 0 & 319 & 348 & 407 & 483 & 647 & 765 \\
\hline $\begin{array}{l}\text { Time for speed of } \\
\text { occupants 1.25 m/s }\end{array}$ & 0 & 287 & 317.6 & 385.7 & 450 & 618.2 & 694 \\
\hline $\begin{array}{l}\text { Time for speed of } \\
\text { occupants 1.5 m/s }\end{array}$ & 0 & 259 & 302 & 359 & 426.2 & 574 & 650 \\
\hline $\begin{array}{l}\text { Time for speed of } \\
\text { occupants 1.75 m/s }\end{array}$ & 0 & 239 & 278.3 & 327 & 384 & 517 & 588 \\
\hline
\end{tabular}


Table 16 - Simulation results in seconds for the third scenario, with elevators enabled and the third and the fourth entrances/exits blocked and for the occupants' speeds from $0.75 \mathrm{~m} / \mathrm{s}, 1 \mathrm{~m} / \mathrm{s}, 1.25 \mathrm{~m} / \mathrm{s}, 1.5 \mathrm{~m} / \mathrm{s}$, and $1.75 \mathrm{~m} / \mathrm{s}$

Таблица 16 - Результаты симуляции, выраженные в секундах по третьему сценарию, с лифтами и с третьим и четвертым заблокированными входами/выходами, учитывая скорость жильцов: $0.75 \mathrm{M} / \mathrm{c}, 1 \mathrm{M} / \mathrm{c}, 1.25 \mathrm{M} / \mathrm{c}, 1.5 \mathrm{M} / \mathrm{c}$ и $1.75 \mathrm{M} / \mathrm{c}$

Табела 16 - Симулациони резултати у секундама за трећи сценарио, са лифртовима и са трећим и четвртим блокираним улазима/излазима, и за брзине станара: $0,75 \mathrm{~m} / \mathrm{s}, 1 \mathrm{~m} / \mathrm{s}, 1,25 \mathrm{~m} / \mathrm{s}, 1,5 \mathrm{~m} / \mathrm{s}$ и $1,75 \mathrm{~m} / \mathrm{s}$

\begin{tabular}{|l|c|c|c|c|c|c|c|}
\hline Number of occupants & 669 & 500 & 400 & 300 & 200 & 100 & 0 \\
\hline $\begin{array}{l}\text { Time for speed of } \\
\text { occupants } 0.75 \mathrm{~m} / \mathrm{s}\end{array}$ & 0 & 346 & 390.5 & 448 & 551 & 711 & 947 \\
\hline $\begin{array}{l}\text { Time for speed of } \\
\text { occupants } 1 \mathrm{~m} / \mathrm{s}\end{array}$ & 0 & 328 & 358.4 & 416 & 493 & 656 & 775.3 \\
\hline $\begin{array}{l}\text { Time for speed of } \\
\text { occupants } 1.25 \mathrm{~m} / \mathrm{s}\end{array}$ & 0 & 297.4 & 325 & 394 & 459 & 628 & 703 \\
\hline $\begin{array}{l}\text { Time for speed of } \\
\text { occupants } 1.5 \mathrm{~m} / \mathrm{s}\end{array}$ & 0 & 268 & 311 & 368 & 434 & 584.3 & 659 \\
\hline $\begin{array}{l}\text { Time for speed of } \\
\text { occupants } 1.75 \mathrm{~m} / \mathrm{s}\end{array}$ & 0 & 248 & 286 & 335.8 & 393 & 526 & 598.3 \\
\hline
\end{tabular}

Table 17 - Simulation results in seconds for the third scenario, with elevators disabled and the first and the second entrances/exits blocked and for the occupants' speeds from $0.75 \mathrm{~m} / \mathrm{s}, 1 \mathrm{~m} / \mathrm{s}, 1.25 \mathrm{~m} / \mathrm{s}, 1.5 \mathrm{~m} / \mathrm{s}$, and $1.75 \mathrm{~m} / \mathrm{s}$

Таблица 17 - Результаты симуляции, выраженные в секундах по третьему сценарию, без лифтта и с первым и вторым заблокированными входами/выходами, учитывая скорость жильцов: $0.75 \mathrm{M} / \mathrm{c}, 1 \mathrm{M} / \mathrm{c}, 1.25 \mathrm{M} / \mathrm{c}, 1.5 \mathrm{M} / \mathrm{c}$ и $1.75 \mathrm{M} / \mathrm{c}$

Табела 17 - Симулациони резултати у секундама за трећи сценарио, без лифттова и са првим и другим блокираним улазима/излазима, и за брзине станара: $0,75 \mathrm{~m} / \mathrm{s}, 1 \mathrm{~m} / \mathrm{s}, 1,25 \mathrm{~m} / \mathrm{s}, 1.5 \mathrm{~m} / \mathrm{s}$ и $1,75 \mathrm{~m} / \mathrm{s}$

\begin{tabular}{|l|c|c|c|c|c|c|c|}
\hline Number of occupants & 669 & 500 & 400 & 300 & 200 & 100 & 0 \\
\hline $\begin{array}{l}\text { Time for speed of } \\
\text { occupants 0.75 m/s }\end{array}$ & 0 & 366 & 410.4 & 570 & 569 & 731 & 966 \\
\hline $\begin{array}{l}\text { Time for speed of } \\
\text { occupants 1 m/s }\end{array}$ & 0 & 348 & 377.5 & 436 & 511.9 & 676 & 794 \\
\hline $\begin{array}{l}\text { Time for speed of } \\
\text { occupants 1.25 m/s }\end{array}$ & 0 & 316 & 346.6 & 413.34 & 479 & 648 & 723 \\
\hline $\begin{array}{l}\text { Time for speed of } \\
\text { occupants } 1.5 \mathrm{~m} / \mathrm{s}\end{array}$ & 0 & 288 & 331.6 & 388 & 454 & 600 & 679 \\
\hline $\begin{array}{l}\text { Time for speed of } \\
\text { occupants } 1.75 \mathrm{~m} / \mathrm{s}\end{array}$ & 0 & 268 & 306 & 356.11 & 413 & 546 & 617 \\
\hline
\end{tabular}


Table 18 - Simulation results in seconds for the third scenario, with elevators disabled and the first and the third entrances/exits blocked and for the occupants' speeds from $0.75 \mathrm{~m} / \mathrm{s}, 1 \mathrm{~m} / \mathrm{s}, 1.25 \mathrm{~m} / \mathrm{s}, 1.5 \mathrm{~m} / \mathrm{s}$, and $1.75 \mathrm{~m} / \mathrm{s}$

Таблица 18 - Результаты симуляции, выраженные в секундах по третьему сценарию, без лифтта и с первым и третьимм заблокированными входами/выходами, учитывая скорость жильцов: $0.75 \mathrm{M} / \mathrm{c}, 1 \mathrm{M} / \mathrm{c}, 1.25 \mathrm{M} / \mathrm{c}, 1.5 \mathrm{M} / \mathrm{c}$ u $1.75 \mathrm{M} / \mathrm{c}$

Табела 18 - Симулациони резултати у секундама за трећи сценарио, без лифртова и са првим и трећим блокираним улазима/излазима, и за брзине станара: 0,75 m/s, $1 \mathrm{~m} / \mathrm{s}, 1,25 \mathrm{~m} / \mathrm{s}, 1,5 \mathrm{~m} / \mathrm{s}$ u $1,75 \mathrm{~m} / \mathrm{s}$

\begin{tabular}{|l|c|c|c|c|c|c|c|}
\hline Number of occupants & 669 & 500 & 400 & 300 & 200 & 100 & 0 \\
\hline $\begin{array}{l}\text { Time for speed of } \\
\text { occupants } 0.75 \mathrm{~m} / \mathrm{s}\end{array}$ & 0 & 377.45 & 420 & 479 & 580 & 742 & 977 \\
\hline $\begin{array}{l}\text { Time for speed of } \\
\text { occupants } 1 \mathrm{~m} / \mathrm{s}\end{array}$ & 0 & 359 & 388 & 447 & 523 & 687.4 & 805 \\
\hline $\begin{array}{l}\text { Time for speed of } \\
\text { occupants } 1.25 \mathrm{~m} / \mathrm{s}\end{array}$ & 0 & 327 & 358 & 424.4 & 425 & 659 & 734.7 \\
\hline $\begin{array}{l}\text { Time for speed of } \\
\text { occupants } 1.5 \mathrm{~m} / \mathrm{s}\end{array}$ & 0 & 299.11 & 341.7 & 399 & 465 & 611.2 & 691.3 \\
\hline $\begin{array}{l}\text { Time for speed of } \\
\text { occupants } 1.75 \mathrm{~m} / \mathrm{s}\end{array}$ & 0 & 279 & 316.7 & 367 & 424 & 557 & 628 \\
\hline
\end{tabular}

Table 19 - Simulation results in seconds for the third scenario, with elevators disabled and the first and the fourth entrances/exits blocked and for the occupants' speeds from $0.75 \mathrm{~m} / \mathrm{s}, 1 \mathrm{~m} / \mathrm{s}, 1.25 \mathrm{~m} / \mathrm{s}, 1.5 \mathrm{~m} / \mathrm{s}$, and $1.75 \mathrm{~m} / \mathrm{s}$

Таблица 19 - Результаты симуляции, выраженные в секундах по третьему сценарию, без лифрта и с первым и четвертым заблокированными входами/выходами, учитывая скорость жильцов: $0.75 \mathrm{M} / \mathrm{c}, 1 \mathrm{M} / \mathrm{c}, 1.25 \mathrm{M} / \mathrm{c}, 1.5 \mathrm{M} / \mathrm{c}$ и $1.75 \mathrm{M} / \mathrm{c}$

Табела 19 - Симулациони резултати у секундама за трећи сценарио, без лифртова и са првим и четвртим блокираним улазима/излазима, и за брзине станара: $0,75 \mathrm{~m} / \mathrm{s}, 1 \mathrm{~m} / \mathrm{s}, 1,25 \mathrm{~m} / \mathrm{s}, 1,5 \mathrm{~m} / \mathrm{s}$ u $1,75 \mathrm{~m} / \mathrm{s}$

\begin{tabular}{|l|c|c|c|c|c|c|c|}
\hline Number of occupants & 669 & 500 & 400 & 300 & 200 & 100 & 0 \\
\hline $\begin{array}{l}\text { Time for speed of } \\
\text { occupants 0.75 m/s }\end{array}$ & 0 & 403.4 & 447 & 503 & 608.4 & 768.3 & 1003 \\
\hline $\begin{array}{l}\text { Time for speed of } \\
\text { occupants 1 m/s }\end{array}$ & 0 & 384.4 & 414.56 & 473 & 550 & 711.6 & 832.1 \\
\hline $\begin{array}{l}\text { Time for speed of } \\
\text { occupants 1.25 m/s }\end{array}$ & 0 & 354 & 383.1 & 451.8 & 516.67 & 685.6 & 759 \\
\hline $\begin{array}{l}\text { Time for speed of } \\
\text { occupants 1.5 m/s }\end{array}$ & 0 & 325 & 368.3 & 424 & 491.34 & 641 & 715 \\
\hline $\begin{array}{l}\text { Time for speed of } \\
\text { occupants 1.75 m/s }\end{array}$ & 0 & 304.7 & 342 & 392.5 & 450.5 & 582 & 655.33 \\
\hline
\end{tabular}


Table 20 - Simulation results in seconds for the third scenario, with elevators disabled and the second and the third entrances/exits blocked and for the occupants' speeds from $0.75 \mathrm{~m} / \mathrm{s}, 1 \mathrm{~m} / \mathrm{s}, 1.25 \mathrm{~m} / \mathrm{s}, 1.5 \mathrm{~m} / \mathrm{s}$, and $1.75 \mathrm{~m} / \mathrm{s}$

Таблица 20 - Результаты симуляции, выраженные в секундах по третьему сценарию, без лифтта и со вторым и третьим заблокированными входами/выходами, учитывая скорость жильцов: $0.75 \mathrm{M} / \mathrm{c}, 1 \mathrm{M} / \mathrm{c}, 1.25 \mathrm{M} / \mathrm{c}, 1.5 \mathrm{M} / \mathrm{c}$ u $1.75 \mathrm{M} / \mathrm{c}$

Табела 20 - Симулациони резултати у секундама за трећи сценарио, без лифртова и са другим и трећим блокираним улазима/излазима, и за брзине станара: 0,75 m/s, $1 \mathrm{~m} / \mathrm{s}, 1,25 \mathrm{~m} / \mathrm{s}, 1,5 \mathrm{~m} / \mathrm{s}$ u $1,75 \mathrm{~m} / \mathrm{s}$

\begin{tabular}{|l|c|c|c|c|c|c|c|}
\hline Number of occupants & 669 & 500 & 400 & 300 & 200 & 100 & 0 \\
\hline $\begin{array}{l}\text { Time for speed of } \\
\text { occupants } 0.75 \mathrm{~m} / \mathrm{s}\end{array}$ & 0 & 347 & 390.66 & 449 & 549 & 711.71 & 948.2 \\
\hline $\begin{array}{l}\text { Time for speed of } \\
\text { occupants } 1 \mathrm{~m} / \mathrm{s}\end{array}$ & 0 & 330.34 & 359.67 & 418 & 493.98 & 658 & 777 \\
\hline $\begin{array}{l}\text { Time for speed of } \\
\text { occupants } 1.25 \mathrm{~m} / \mathrm{s}\end{array}$ & 0 & 298 & 328.6 & 394.9 & 461.5 & 628.8 & 705.29 \\
\hline $\begin{array}{l}\text { Time for speed of } \\
\text { occupants } 1.5 \mathrm{~m} / \mathrm{s}\end{array}$ & 0 & 269.2 & 312.7 & 369.5 & 436 & 580.2 & 661 \\
\hline $\begin{array}{l}\text { Time for speed of } \\
\text { occupants } 1.75 \mathrm{~m} / \mathrm{s}\end{array}$ & 0 & 251.12 & 289.4 & 339.2 & 394.5 & 529.45 & 599 \\
\hline
\end{tabular}

Table 21 - Simulation results in seconds for the third scenario, with elevators disabled and the second and the fourth entrances/exits blocked and for the occupants' speeds from $0.75 \mathrm{~m} / \mathrm{s}, 1 \mathrm{~m} / \mathrm{s}, 1.25 \mathrm{~m} / \mathrm{s}, 1.5 \mathrm{~m} / \mathrm{s}$, and $1.75 \mathrm{~m} / \mathrm{s}$

Таблица 21 - Результаты симуляции, выраженные в секундах по третьему сценарию, без лифта и со вторым и четвертым заблокированными входами/выходами, учитывая скорость жильцов: $0.75 \mathrm{~m} / \mathrm{c}, 1 \mathrm{~m} / \mathrm{c}, 1.25 \mathrm{M} / \mathrm{c}, 1.5 \mathrm{~m} / \mathrm{c}$ u $1.75 \mathrm{M} / \mathrm{c}$

Табела 21 - Симулациони резултати у секундама за трећи сценарио, без лифттова и са другим и четвртим блокираним улазима/излазима, и за брзине станара: $0,75 \mathrm{~m} / \mathrm{s}, 1 \mathrm{~m} / \mathrm{s}, 1,25 \mathrm{~m} / \mathrm{s}, 1,5 \mathrm{~m} / \mathrm{s}$ u $1,75 \mathrm{~m} / \mathrm{s}$

\begin{tabular}{|l|c|c|c|c|c|c|c|}
\hline \multicolumn{1}{|c|}{ Number of occupants } & 669 & 500 & 400 & 300 & 200 & 100 & 0 \\
\hline $\begin{array}{l}\text { Time for speed of } \\
\text { occupants } 0.75 \mathrm{~m} / \mathrm{s}\end{array}$ & 0 & 383 & 428 & 487 & 590 & 750 & 989 \\
\hline $\begin{array}{l}\text { Time for speed of } \\
\text { occupants } 1 \mathrm{~m} / \mathrm{s}\end{array}$ & 0 & 368 & 396 & 455 & 531 & 695 & 813 \\
\hline $\begin{array}{l}\text { Time for speed of } \\
\text { occupants 1.25 m/s }\end{array}$ & 0 & 335.7 & 364 & 434.29 & 498 & 667 & 742 \\
\hline $\begin{array}{l}\text { Time for speed of } \\
\text { occupants } 1.5 \mathrm{~m} / \mathrm{s}\end{array}$ & 0 & 307.56 & 350 & 407 & 474.2 & 622 & 698 \\
\hline $\begin{array}{l}\text { Time for speed of } \\
\text { occupants } 1.75 \mathrm{~m} / \mathrm{s}\end{array}$ & 0 & 287.2 & 326.3 & 376.06 & 432.22 & 566.45 & 636 \\
\hline
\end{tabular}


Table 22 - Simulation results in seconds for the third scenario, with elevators disabled and the third and the fourth entrances/exits blocked and for the occupants' speeds from $0.75 \mathrm{~m} / \mathrm{s}, 1 \mathrm{~m} / \mathrm{s}, 1.25 \mathrm{~m} / \mathrm{s}, 1.5 \mathrm{~m} / \mathrm{s}$, and $1.75 \mathrm{~m} / \mathrm{s}$

Таблица 22 - Результаты симуляции, выраженные в секундах по третьему сценарию,

без лифта и с третьим и четвертым заблокированными входами/выходами, учитывая скорость жильцов: $0.75 \mathrm{M} / \mathrm{c}, 1 \mathrm{M} / \mathrm{c}, 1.25 \mathrm{M} / \mathrm{c}, 1.5 \mathrm{M} / \mathrm{c}$ u $1.75 \mathrm{M} / \mathrm{c}$

Табела 22 - Симулациони резултати у секундама за трећи сценарио, без лифртова и са трећим и четвртим блокираним улазима/излазима, и за брзине станара: $0,75 \mathrm{~m} / \mathrm{s}, 1 \mathrm{~m} / \mathrm{s}, 1,25 \mathrm{~m} / \mathrm{s}, 1,5 \mathrm{~m} / \mathrm{s}$ и $1,75 \mathrm{~m} / \mathrm{s}$

\begin{tabular}{|l|c|c|c|c|c|c|c|}
\hline Number of occupants & 669 & 500 & 400 & 300 & 200 & 100 & 0 \\
\hline $\begin{array}{l}\text { Time for speed of } \\
\text { occupants 0.75 m/s }\end{array}$ & 0 & 393.23 & 438 & 496.6 & 599.3 & 758 & 995.27 \\
\hline $\begin{array}{l}\text { Time for speed of } \\
\text { occupants 1 m/s }\end{array}$ & 0 & 374.9 & 405.37 & 463.78 & 541.12 & 703 & 822.3 \\
\hline $\begin{array}{l}\text { Time for speed of } \\
\text { occupants 1.25 m/s }\end{array}$ & 0 & 344.4 & 372.3 & 441 & 506 & 674.88 & 750.31 \\
\hline $\begin{array}{l}\text { Time for speed of } \\
\text { occupants } 1.5 \mathrm{~m} / \mathrm{s}\end{array}$ & 0 & 317 & 358 & 415 & 481 & 631.3 & 707.3 \\
\hline $\begin{array}{l}\text { Time for speed of } \\
\text { occupants } 1.75 \mathrm{~m} / \mathrm{s}\end{array}$ & 0 & 296.6 & 335 & 382.8 & 440 & 573 & 645.3 \\
\hline
\end{tabular}

Table 23 - Simulation results in seconds for the fourth scenario, with elevators enabled and the first entrance/exit opened, while the second, the third and the fourth

entrances/exits are blocked, and for the occupants' speeds from $0.75 \mathrm{~m} / \mathrm{s}, 1 \mathrm{~m} / \mathrm{s}, 1.25$ $\mathrm{m} / \mathrm{s}, 1.5 \mathrm{~m} / \mathrm{s}$, and $1.75 \mathrm{~m} / \mathrm{s}$

Таблица 23 - Результаты симуляции, выраженные в секундах по четвертому

сценарию, с лифтами и с первым открытым входом/выходом, в то время как второй, третий и четвертый входы/выходы заблокированы, учитывая скорость жильцов: $0.75 \mathrm{M} / \mathrm{c}, 1 \mathrm{M} / \mathrm{c}, 1.25 \mathrm{M} / \mathrm{c}, 1.5 \mathrm{M} / \mathrm{c}$ и $1.75 \mathrm{M} / \mathrm{c}$

Табела 23 - Симулациони резултати у секундама за четврти сценарио, са лифтовима и са првим отвореним улазом/излазом, док су други, трећи и четврти улази/излази блокирани, и за брзине станара: 0,75 m/s, $1 \mathrm{~m} / \mathrm{s}, 1,25 \mathrm{~m} / \mathrm{s}$, $1,5 \mathrm{~m} / \mathrm{s}$ u $1,75 \mathrm{~m} / \mathrm{s}$

\begin{tabular}{|l|c|c|c|c|c|c|c|}
\hline Number of occupants & 669 & 500 & 400 & 300 & 200 & 100 & 0 \\
\hline $\begin{array}{l}\text { Time for speed of } \\
\text { occupants 0.75 m/s }\end{array}$ & 0 & 443.6 & 678.3 & 915.9 & 1150.7 & 1388.3 & 1623 \\
\hline $\begin{array}{l}\text { Time for speed of } \\
\text { occupants 1 m/s }\end{array}$ & 0 & 322 & 496.5 & 672 & 846.3 & 1021.8 & 1198.3 \\
\hline $\begin{array}{l}\text { Time for speed of } \\
\text { occupants 1.25 m/s }\end{array}$ & 0 & 310 & 470 & 620 & 780 & 834 & 992 \\
\hline $\begin{array}{l}\text { Time for speed of } \\
\text { occupants 1.5 m/s }\end{array}$ & 0 & 304 & 432.6 & 594 & 700 & 800 & 900 \\
\hline $\begin{array}{l}\text { Time for speed of } \\
\text { occupants 1.75 m/s }\end{array}$ & 0 & 274 & 373.4 & 474.9 & 585.5 & 689 & 794 \\
\hline
\end{tabular}


Table 24 - Simulation results in seconds for the fourth scenario, with elevators enabled and the second entrance/exit opened, while the first, the third and the fourth entrances/exits are blocked, and for the occupants' speeds from $0.75 \mathrm{~m} / \mathrm{s}, 1 \mathrm{~m} / \mathrm{s}, 1.25$ $\mathrm{m} / \mathrm{s}, 1.5 \mathrm{~m} / \mathrm{s}$, and $1.75 \mathrm{~m} / \mathrm{s}$

Таблица 24 - Результаты симуляции, выраженные в секундах по четвертому сценарию, с лифртами и со вторым открытым входом/выходом в то время как первый, третий и четвертый входы/выходы заблокированы, учитывая скорость жильцов: $0.75 \mathrm{M} / \mathrm{c}, 1 \mathrm{M} / \mathrm{c}, 1.25 \mathrm{M} / \mathrm{c}, 1.5 \mathrm{M} / \mathrm{c}$ и $1.75 \mathrm{M} / \mathrm{c}$

Табела 24 - Симулациони резултати у секундама за четврти сценарио, са лифтовима и са другим отвореним улазом/излазом, док су први, трећи u четврти улази/излази блокирани, и за брзине станара: 0,75 m/s, $1 \mathrm{~m} / \mathrm{s}, 1,25 \mathrm{~m} / \mathrm{s}$, $1,5 \mathrm{~m} / \mathrm{s}$ u $1,75 \mathrm{~m} / \mathrm{s}$

\begin{tabular}{|l|c|c|c|c|c|c|c|}
\hline Number of occupants & 669 & 500 & 400 & 300 & 200 & 100 & 0 \\
\hline $\begin{array}{l}\text { Time for speed of } \\
\text { occupants } 0.75 \mathrm{~m} / \mathrm{s}\end{array}$ & 0 & 483.2 & 718.8 & 949.6 & 1183 & 1414.3 & 1646.5 \\
\hline $\begin{array}{l}\text { Time for speed of } \\
\text { occupants 1 m/s }\end{array}$ & 0 & 335 & 515 & 694 & 869 & 1044.6 & 1220.3 \\
\hline $\begin{array}{l}\text { Time for speed of } \\
\text { occupants } 1.25 \mathrm{~m} / \mathrm{s}\end{array}$ & 0 & 286 & 426.4 & 566.8 & 707.8 & 849.1 & 988.6 \\
\hline $\begin{array}{l}\text { Time for speed of } \\
\text { occupants } 1.5 \mathrm{~m} / \mathrm{s}\end{array}$ & 0 & 263 & 404.5 & 531.6 & 651.7 & 772.6 & 890.3 \\
\hline $\begin{array}{l}\text { Time for speed of } \\
\text { occupants } 1.75 \mathrm{~m} / \mathrm{s}\end{array}$ & 0 & 242.3 & 355.2 & 463.2 & 569.8 & 675.7 & 780.2 \\
\hline
\end{tabular}

Table 25 - Simulation results in seconds for the fourth scenario, with elevators enabled and the third entrance/exit opened, while the first, the second and the fourth entrances/exits are blocked, and for the occupants' speeds from $0.75 \mathrm{~m} / \mathrm{s}, 1 \mathrm{~m} / \mathrm{s}, 1.25$ $\mathrm{m} / \mathrm{s}, 1.5 \mathrm{~m} / \mathrm{s}$, and $1.75 \mathrm{~m} / \mathrm{s}$

Таблица 25 - Результаты симуляции, выраженные в секундах по четвертому сценарию, с лифтами и с третьим открытым входом/выходом, в то время как первый, второй и четвертый входы/выходы заблокированы, учитывая скорость жильцов: $0.75 \mathrm{M} / \mathrm{c}, 1 \mathrm{M} / \mathrm{c}, 1.25 \mathrm{M} / \mathrm{c}, 1.5 \mathrm{M} / \mathrm{c}$ и $1.75 \mathrm{M} / \mathrm{c}$

Табела 25 - Симулациони резултати у секундама за четврти сценарио, са лифотовима и са трећим отвореним улазом/излазом, док су први, други и четврти улази/излази блокирани, и за брзине станара: 0,75 m/s, $1 \mathrm{~m} / \mathrm{s}, 1,25 \mathrm{~m} / \mathrm{s}$, $1,5 \mathrm{~m} / \mathrm{s}$ u $1,75 \mathrm{~m} / \mathrm{s}$

\begin{tabular}{|l|c|c|c|c|c|c|c|}
\hline Number of occupants & 669 & 500 & 400 & 300 & 200 & 100 & 0 \\
\hline $\begin{array}{l}\text { Time for speed of } \\
\text { occupants 0.75 m/s }\end{array}$ & 0 & 443.7 & 680 & 917.6 & 1152.5 & 1390.2 & 1623.6 \\
\hline $\begin{array}{l}\text { Time for speed of } \\
\text { occupants 1 m/s }\end{array}$ & 0 & 336.6 & 510 & 686 & 861.6 & 1036.5 & 1204.7 \\
\hline $\begin{array}{l}\text { Time for speed of } \\
\text { occupants 1.25 m/s }\end{array}$ & 0 & 264.8 & 400 & 540.8 & 681.4 & 823.4 & 962.8 \\
\hline $\begin{array}{l}\text { Time for speed of } \\
\text { occupants 1.5 m/s }\end{array}$ & 0 & 247.4 & 387.5 & 519.6 & 641.4 & 763.7 & 884.5 \\
\hline $\begin{array}{l}\text { Time for speed of } \\
\text { occupants } 1.75 \mathrm{~m} / \mathrm{s}\end{array}$ & 0 & 241.3 & 351.7 & 460 & 565.3 & 669.6 & 800 \\
\hline
\end{tabular}


Table 26 - Simulation results in seconds for the fourth scenario, with elevators enabled and the fourth entrance/exit opened, while the first, the second and the third entrances/exits are blocked, and for the occupants' speeds from $0.75 \mathrm{~m} / \mathrm{s}, 1 \mathrm{~m} / \mathrm{s}, 1.25$ $\mathrm{m} / \mathrm{s}, 1.5 \mathrm{~m} / \mathrm{s}$, and $1.75 \mathrm{~m} / \mathrm{s}$

Таблица 26 - Результаты симуляции, выраженные в секундах по четвертому сценарию, с лифотами и с четвертым открытым входом/выходом, в то время как первый, второй и третий входы/выходы заблокированы, учитывая скорость жильцов: $0.75 \mathrm{M} / \mathrm{c}, 1 \mathrm{M} / \mathrm{c}, 1.25 \mathrm{M} / \mathrm{c}, 1.5 \mathrm{M} / \mathrm{c}$ и $1.75 \mathrm{M} / \mathrm{c}$

Табела 26 - Симулациони резултати у секундама за четврти сценарио, са лисртовима и са четвртим отвореним улазом/излазом, док су први, други и mрећи улази излази блокирани, и за брзине станара: 0,75 m/s, $1 \mathrm{~m} / \mathrm{s}, 1,25 \mathrm{~m} / \mathrm{s}, 1,5$

\begin{tabular}{|l|c|c|c|c|c|c|c|}
\hline Number of occupants & 669 & 500 & 400 & 300 & 200 & 100 & 0 \\
\hline $\begin{array}{l}\text { Time for speed of } \\
\text { occupants 0.75 m/s }\end{array}$ & 0 & 446 & 677 & 910 & 1145 & 1376.9 & 1603.6 \\
\hline $\begin{array}{l}\text { Time for speed of } \\
\text { occupants 1 m/s }\end{array}$ & 0 & 332 & 509.6 & 709 & 857.6 & 1032.1 & 1206 \\
\hline $\begin{array}{l}\text { Time for speed of } \\
\text { occupants 1.25 m/s }\end{array}$ & 0 & 320 & 487 & 683 & 832 & 992 & 1132 \\
\hline $\begin{array}{l}\text { Time for speed of } \\
\text { occupants 1.5 m/s }\end{array}$ & 0 & 302 & 457 & 588.4 & 714.5 & 836.6 & 953.7 \\
\hline $\begin{array}{l}\text { Time for speed of } \\
\text { occupants 1.75 m/s }\end{array}$ & 0 & 295.4 & 406.7 & 539.5 & 648.6 & 754.7 & 860 \\
\hline
\end{tabular}

Table 27 - Simulation results in seconds for the fourth scenario, with elevators disabled and the first entrance/exit opened, while the second, the third and the fourth entrances/exits are blocked, and for the occupants' speeds from $0.75 \mathrm{~m} / \mathrm{s}, 1 \mathrm{~m} / \mathrm{s}, 1.25$ $\mathrm{m} / \mathrm{s}, 1.5 \mathrm{~m} / \mathrm{s}$, and $1.75 \mathrm{~m} / \mathrm{s}$

Таблица 27 - Результаты симуляции, выраженные в секундах по четвертому сценарию, без лифрта и с первым открытым входом/выходом, в то время как второй, третий и четвертый входы/выходы заблокированы, учитывая скорость жильцов: $0.75 \mathrm{M} / \mathrm{c}, 1 \mathrm{M} / \mathrm{c}, 1.25 \mathrm{M} / \mathrm{c}, 1.5 \mathrm{M} / \mathrm{c}$ и $1.75 \mathrm{M} / \mathrm{c}$

Табела 27 - Симулациони резултати у секундама за четврти сценарио, без лифтова и са првим отвореним улазом/излазом, док су други, трећи и четврти улази/излази блокирани, и за брзине станара: 0,75 m/s, $1 \mathrm{~m} / \mathrm{s}, 1,25 \mathrm{~m} / \mathrm{s}, 1,5 \mathrm{~m} / \mathrm{s} \mathrm{u}$

\begin{tabular}{|l|c|c|c|c|c|c|c|}
\hline Number of occupants & 669 & 500 & 400 & 300 & 200 & 100 & 0 \\
\hline $\begin{array}{l}\text { Time for speed of } \\
\text { occupants 0.75 m/s }\end{array}$ & 0 & 550.3 & 787 & 1021.9 & 1257.4 & 1493.5 & 1729.3 \\
\hline $\begin{array}{l}\text { Time for speed of } \\
\text { occupants 1 m/s }\end{array}$ & 0 & 428 & 602 & 778.5 & 953 & 1126.9 & 1302 \\
\hline $\begin{array}{l}\text { Time for speed of } \\
\text { occupants 1.25 m/s }\end{array}$ & 0 & 416.1 & 576 & 726.54 & 885.3 & 940 & 1099.3 \\
\hline $\begin{array}{l}\text { Time for speed of } \\
\text { occupants 1.5 m/s }\end{array}$ & 0 & 410.32 & 538 & 701.5 & 806.4 & 906.2 & 1006 \\
\hline $\begin{array}{l}\text { Time for speed of } \\
\text { occupants 1.75 m/s }\end{array}$ & 0 & 380.5 & 480 & 580.9 & 693.4 & 795 & 900.02 \\
\hline
\end{tabular}


Table 28 - Simulation results in seconds for the fourth scenario, with elevators disabled and the second entrance/exit opened, while the first, the third and the fourth entrances/exits are blocked, and for the occupants' speeds from $0.75 \mathrm{~m} / \mathrm{s}, 1 \mathrm{~m} / \mathrm{s}, 1.25$ $\mathrm{m} / \mathrm{s}, 1.5 \mathrm{~m} / \mathrm{s}$, and $1.75 \mathrm{~m} / \mathrm{s}$

Таблица 28 - Результаты симуляции, выраженные в секундах по четвертому сценарию, без лифота и со вторым открытым входом/выходом, в то время как первый, третий и четвертый входы/выходы заблокированы, учитывая скорость жильцов: $0.75 \mathrm{M} / \mathrm{c}, 1 \mathrm{M} / \mathrm{c}, 1.25 \mathrm{M} / \mathrm{c}, 1.5 \mathrm{M} / \mathrm{c}$ и $1.75 \mathrm{M} / \mathrm{c}$

Табела 28 - Симулациони резултати и секундама за четврти сценарио, без лисртова и са другим отвореним улазом/излазом, док су први, трећи и четврти улази/излази блокирани, и за брзине станара: 0,75 m/s, $1 \mathrm{~m} / \mathrm{s}, 1,25 \mathrm{~m} / \mathrm{s}, 1,5 \mathrm{~m} / \mathrm{s}$ u

\begin{tabular}{|l|c|c|c|c|c|c|c|}
\hline Number of occupants & 669 & 500 & 400 & 300 & 200 & 100 & 0 \\
\hline $\begin{array}{l}\text { Time for speed of } \\
\text { occupants } 0.75 \mathrm{~m} / \mathrm{s}\end{array}$ & 0 & 547 & 781 & 1019.9 & 1255 & 1493 & 1727 \\
\hline $\begin{array}{l}\text { Time for speed of } \\
\text { occupants } 1 \mathrm{~m} / \mathrm{s}\end{array}$ & 0 & 426.2 & 600 & 776 & 951 & 1126 & 1303.5 \\
\hline $\begin{array}{l}\text { Time for speed of } \\
\text { occupants 1.25 m/s }\end{array}$ & 0 & 413.34 & 574.7 & 723.4 & 882.4 & 938.4 & 1096.71 \\
\hline $\begin{array}{l}\text { Time for speed of } \\
\text { occupants 1.5 m/s }\end{array}$ & 0 & 408 & 539.17 & 699.8 & 804 & 904 & 1003.4 \\
\hline $\begin{array}{l}\text { Time for speed of } \\
\text { occupants 1.75 m/s }\end{array}$ & 0 & 378 & 476.6 & 579 & 890 & 793 & 898 \\
\hline
\end{tabular}

Table 29 - Simulation results in seconds for the fourth scenario, with elevators disabled and the third entrance/exit opened, while the first, the second and the fourth

entrances/exits are blocked, and for the occupants' speeds from $0.75 \mathrm{~m} / \mathrm{s}, 1 \mathrm{~m} / \mathrm{s}, 1.25$ $\mathrm{m} / \mathrm{s}, 1.5 \mathrm{~m} / \mathrm{s}$, and $1.75 \mathrm{~m} / \mathrm{s}$

Таблица 29 - Результаты симуляции, выраженные в секундах по четвертому сценарию, без лифтта и с третьим открытым входом/выходом, в то время как первый, второй и четвертый входы/выходы заблокированы, учитывая скорость жильцов: $0.75 \mathrm{M} / \mathrm{c}, 1 \mathrm{~m} / \mathrm{c}, 1.25 \mathrm{M} / \mathrm{c}, 1.5 \mathrm{M} / \mathrm{c}$ и $1.75 \mathrm{M} / \mathrm{c}$

Табела 29 - Симулациони резултати у секундама за четврти сценарио, без лифтова и са трећим отвореним улазом/излазом, док су први, други и четврти улази/излази блокирани, и за брзине станара: 0,75 m/s, $1 \mathrm{~m} / \mathrm{s}, 1,25 \mathrm{~m} / \mathrm{s}, 1,5 \mathrm{~m} / \mathrm{s} \mathrm{u}$

\begin{tabular}{|l|c|c|c|c|c|c|c|}
\hline \multicolumn{1}{|c|}{ Number of occupants } & 669 & 500 & 400 & 300 & 200 & 100 & 0 \\
\hline $\begin{array}{l}\text { Time for speed of } \\
\text { occupants 0.75 m/s }\end{array}$ & 0 & 545.02 & 781.4 & 1018.6 & 1254 & 1492 & 1725 \\
\hline $\begin{array}{l}\text { Time for speed of } \\
\text { occupants 1 m/s }\end{array}$ & 0 & 438 & 612.11 & 787 & 963.9 & 1137 & 1305 \\
\hline $\begin{array}{l}\text { Time for speed of } \\
\text { occupants 1.25 m/s }\end{array}$ & 0 & 365.16 & 500.31 & 643.2 & 787 & 925 & 1064.8 \\
\hline $\begin{array}{l}\text { Time for speed of } \\
\text { occupants 1.5 m/s }\end{array}$ & 0 & 349 & 489 & 621.7 & 743 & 867.5 & 986 \\
\hline $\begin{array}{l}\text { Time for speed of } \\
\text { occupants 1.75 m/s }\end{array}$ & 0 & 343.6 & 453 & 561 & 667.8 & 771 & 902.3 \\
\hline
\end{tabular}


Table 30 - Simulation results in seconds for the fourth scenario, with elevators disabled and the fourth entrance/exit opened, while the first, the second and the third entrances/exits are blocked, and for the occupants' speeds from $0.75 \mathrm{~m} / \mathrm{s}, 1 \mathrm{~m} / \mathrm{s}, 1.25$ $\mathrm{m} / \mathrm{s}, 1.5 \mathrm{~m} / \mathrm{s}$, and $1.75 \mathrm{~m} / \mathrm{s}$

Таблица 30 - Результаты симуляции, выраженные в секундах по четвертому сценарию, без лифтта и с четвертым открытым входом/выходом, в то время как первый, второй и третий входы/выходы заблокированы, учитывая скорость жильцов: $0.75 \mathrm{M} / \mathrm{c}, 1 \mathrm{M} / \mathrm{c}, 1.25 \mathrm{M} / \mathrm{c}, 1.5 \mathrm{M} / \mathrm{c}$ u $1.75 \mathrm{M} / \mathrm{c}$

Табела 30 - Симулациони резултати у секундама за четврти сценарио, без лифртова и са четвртим отвореним улазом/излазом, док су први, други и трећи улази/излази блокирани, и за брзине станара: 0,75 m/s, $1 \mathrm{~m} / \mathrm{s}, 1,25 \mathrm{~m} / \mathrm{s}, 1,5 \mathrm{~m} / \mathrm{s}$ u

\begin{tabular}{|l|c|c|c|c|c|c|c|}
\hline Number of occupants & 669 & 500 & 400 & 300 & 200 & 100 & 0 \\
\hline $\begin{array}{l}\text { Time for speed of } \\
\text { occupants 0.75 m/s }\end{array}$ & 0 & 543.6 & 776.7 & 1009 & 1243 & 1476 & 1702 \\
\hline $\begin{array}{l}\text { Time for speed of } \\
\text { occupants 1 m/s }\end{array}$ & 0 & 431.31 & 608.29 & 808.3 & 955 & 1130 & 1306.8 \\
\hline $\begin{array}{l}\text { Time for speed of } \\
\text { occupants } 1.25 \mathrm{~m} / \mathrm{s}\end{array}$ & 0 & 417.23 & 587.6 & 782 & 931 & 1091 & 1231.4 \\
\hline $\begin{array}{l}\text { Time for speed of } \\
\text { occupants } 1.5 \mathrm{~m} / \mathrm{s}\end{array}$ & 0 & 401.5 & 556.9 & 688 & 811.3 & 936.24 & 1053 \\
\hline $\begin{array}{l}\text { Time for speed of } \\
\text { occupants } 1.75 \mathrm{~m} / \mathrm{s}\end{array}$ & 0 & 394 & 504.75 & 636.18 & 746 & 850.53 & 959 \\
\hline
\end{tabular}

\section{Results analysis}

The realized simulation results for the first scenario (Tables 1 and 2) have shown that the elevators usage increases the evacuation of the complete object. The fastest evacuation time was for the occupants' speed of $1.75 \mathrm{~m} / \mathrm{s}$ and the elevators enabled (209 seconds, in Table 1), while the slowest evacuation time was for the occupants' speed of 0.75 $\mathrm{m} / \mathrm{s}$ and the elevators disabled (442 seconds, in Table 2). In this scenario, the occupants left the building via their own entrance/exit. There were no jams for simulated occupants' speeds.

The realized simulation results for the second scenario (Tables from 3 to 10) have shown that the fastest evacuation time was realized when the occupants' speed was $1.75 \mathrm{~m} / \mathrm{s}$, the second entrance/exit blocked and the elevators enabled (422 seconds, in Table 4). The slowest evacuation time was realized when the occupants' speed was $0.75 \mathrm{~m} / \mathrm{s}$, the fourth entrance/exit blocked and the elevators disabled (893 seconds, in Table 10). In this scenario, the occupants from the building with the blocked entrance/exit had to use the building roof terraces to reach the 
nearest stairs that lead to the open entrance/exit. There were no jams for the simulated occupants' speeds. Some simulation scenes from the second scenario are presented in Figure 3 ( $a$ and $b)$.

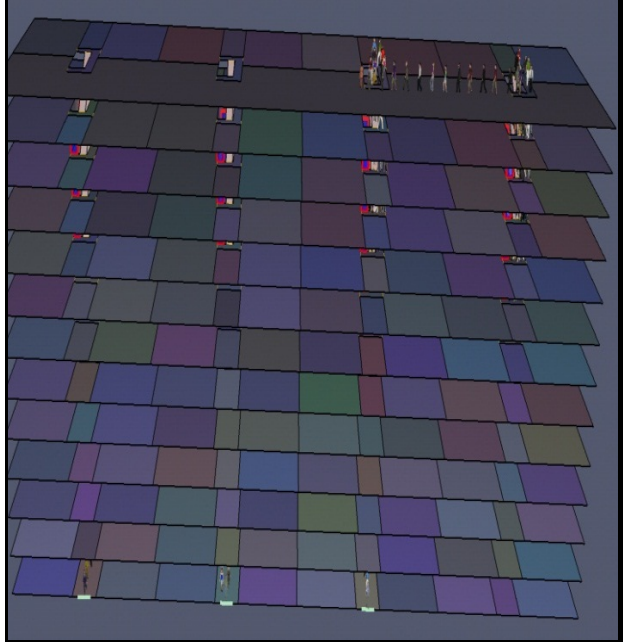

a)

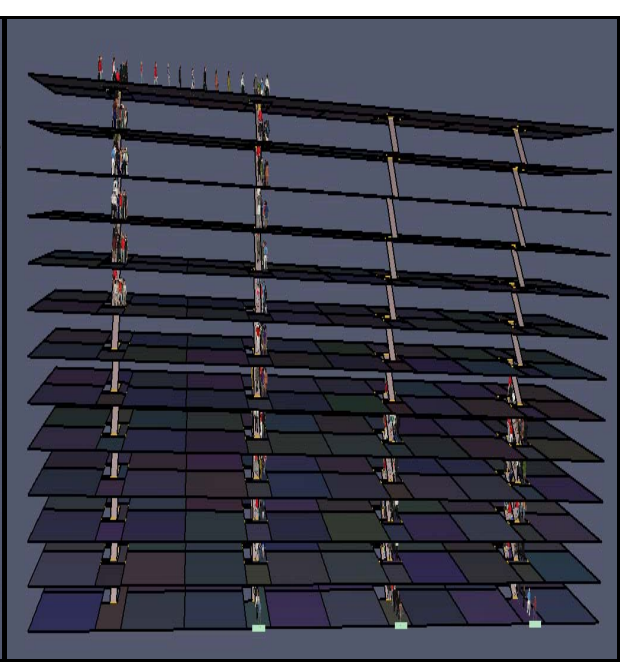

b)

Figure 3. Simulation scene for the second scenario where the first entrance/exit was blocked and the elevators were enabled and for the occupants' speeds of $1 \mathrm{~m} / \mathrm{s}$ (a) and the simulation scene for the second scenario where the fourth entrance/exit was blocked and the elevators were disabled and for the occupants' speeds of $0.75 \mathrm{~m} / \mathrm{s}$ (b)

Puc. 3 - Имитационные сцены по второму сценарию, в котором первый вход/выход заблокирован и есть лифты, учитывая скорость жильцов: $0.75 \mathrm{~m} / \mathrm{c}, 1$ M/c, 1.25 м/c, 1.5 м/с и 1.75 M/c (a), и имитационные сцены по второму сценарию, в котором четвертый вход/выход заблокирован и нет лифта, учитывая скорость жильцов: $0.75 \mathrm{M} / \mathrm{c}, 1 \mathrm{M} / \mathrm{c}, 1.25 \mathrm{M} / \mathrm{c}, 1.5 \mathrm{~m} / \mathrm{c}$ u $1.75 \mathrm{M} / \mathrm{c}$ (б)

Слика 3 - Симулационе сцене из другог сценарија где је први улаз/излаз блокиран и са лифтовима и за брзине станара: 0,75 m/s, $1 \mathrm{~m} / \mathrm{s}, 1,25 \mathrm{~m} / \mathrm{s}, 1,5 \mathrm{~m} / \mathrm{s} \mathrm{u} \mathrm{1,75} \mathrm{m/s}$ (a), и симулационе сцене из другог сценарија где је четврти улаз/излаз блокиран и без лифртова, и за брзине станара: 0,75 m/s, $1 \mathrm{~m} / \mathrm{s}, 1,25 \mathrm{~m} / \mathrm{s}, 1,5 \mathrm{~m} / \mathrm{s} \mathrm{u} \mathrm{1,75} \mathrm{m/s} \mathrm{(б)}$

The realized simulation results for the third scenario (Tables from 11 to 22) have shown that the fastest evacuation time was realized when the occupants' speed was $1.75 \mathrm{~m} / \mathrm{s}$, the second and the third entrances/exits blocked and the elevators enabled (550 seconds, in Table 14). The slowest evacuation time was realized when the occupants' speed was $0.75 \mathrm{~m} / \mathrm{s}$, with the first and the fourth entrances/exits blocked and the elevators disabled (1003 seconds, in Table 19). In this scenario, the occupants from the buildings with the blocked entrances/exits had to use the building roof terraces to reach the nearest stairs that lead to the open entrance/exit. The simulations showed that jams can occur, mostly for 
the occupants' speed of $0.75 \mathrm{~m} / \mathrm{s}$ and $1.25 \mathrm{~m} / \mathrm{s}$. Some simulation scenes from the third scenario are presented in Figure 4 ( $a$ and $b$ ).

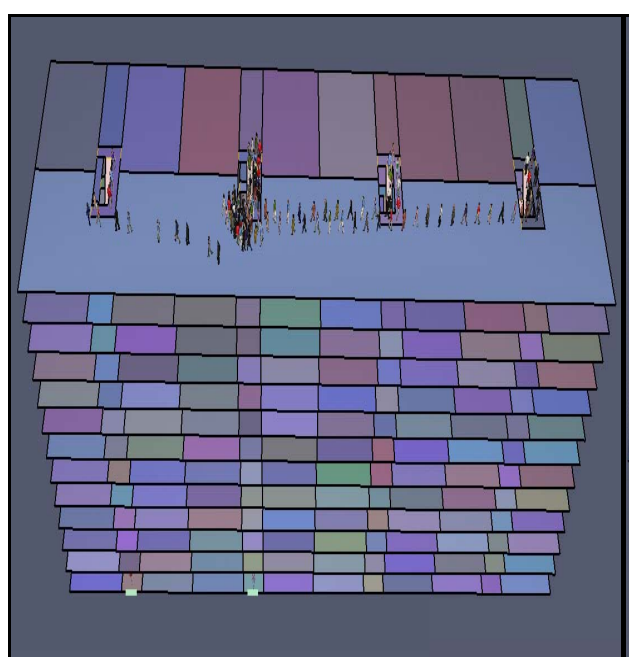

a)

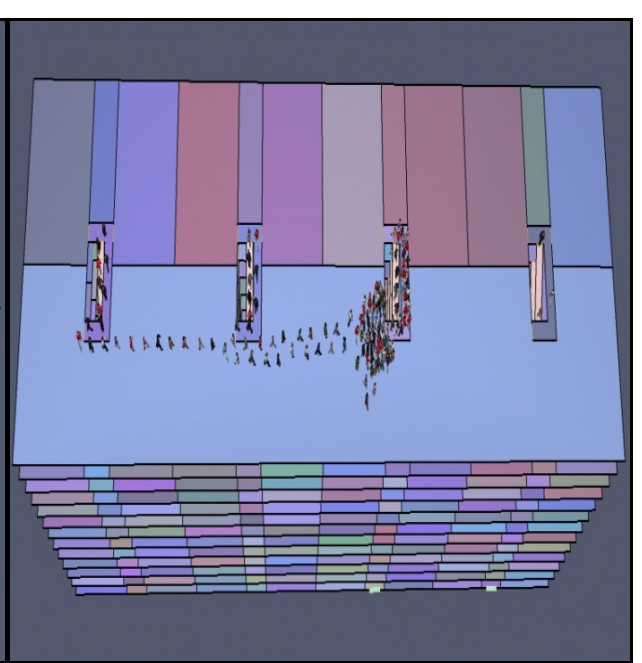

b)

Figure 4-Simulation scene for the third scenario where the first and the second entrances/exits were blocked and the elevators were enabled and for the occupants' speeds of $1.25 \mathrm{~m} / \mathrm{s}$ (a) and a simulation scene for the third scenario where the third and the fourth entrances/exits were blocked and the elevators were disabled and for the occupants' speeds of $1.5 \mathrm{~m} / \mathrm{s}$ (b)

Puc. 4 - Имитационные сцены по третьему сценарию, в котором первый и

второй входы/выходы заблокированы и есть лифты, учитывая скорость жильцов: $0.75 \mathrm{M} / \mathrm{c}, 1 \mathrm{M} / \mathrm{c}, 1.25 \mathrm{M} / \mathrm{c}, 1.5 \mathrm{M} / \mathrm{c}$ и $1.75 \mathrm{~m} / \mathrm{c}$ (a) и имитационные сцены по третьему сценарию, в котором третий и четвертый входы/выходы заблокированы и нет лифта, учитывая скорость жильщов: 0.75 м/с, 1 м/c, 1.25 $\mathrm{M} / \mathrm{c}, 1.5 \mathrm{M} / \mathrm{c}$ и $1.75 \mathrm{M} / \mathrm{c}$ (б)

Слика 4 - Симулационе сцене из трећег сценарија где су први и други улазиизлази блокирани и са лифтовима и за брзине станара: 0,75 m/s, $1 \mathrm{~m} / \mathrm{s}, 1,25$ $\mathrm{m} / \mathrm{s}, 1,5 \mathrm{~m} / \mathrm{s}$ и $1,75 \mathrm{~m} / \mathrm{s}($ (а), и симулационе сцене из трећег сценарија, где су трећи и четврти улазиизлази блокирани и без лифтова, и за брзине станара: 0,75 m/s, $1 \mathrm{~m} / \mathrm{s}, 1,25 \mathrm{~m} / \mathrm{s}, 1,5 \mathrm{~m} / \mathrm{s}$ u $1,75 \mathrm{~m} / \mathrm{s}$ (б)

The realized simulation results for the fourth scenario (Tables from 23 to 30 ) have shown that the fastest evacuation time was realized when the occupants' speed was $1.75 \mathrm{~m} / \mathrm{s}$, the first entrance/exit opened and the second, the third and the fourth entrances/exits blocked and the elevators enabled (794 seconds, in Table 23). The slowest evacuation time was realized when the occupants' speed was $0.75 \mathrm{~m} / \mathrm{s}$; with the first entrance/exit opened, and with the second, the third and the fourth entrances/exits blocked and the elevators disabled (1729.3 seconds, in 
Table 27). In this scenario, the occupants with the blocked entrances/exits had to use the building roof terraces to reach the nearest stairs that lead to the single open entrance/exit. The simulations showed that jams can occur, mostly for the occupants' speed of $0.75 \mathrm{~m} / \mathrm{s}$. The simulations showed that jams in this scenario can occur and that these jams can be significant, for every occupants' speed from $0.75 \mathrm{~m} / \mathrm{s}$ to 1.75 $\mathrm{m} / \mathrm{s}$. Some simulation scenes from the fourth scenario are presented in Figure 5 ( $a$ and $b)$.

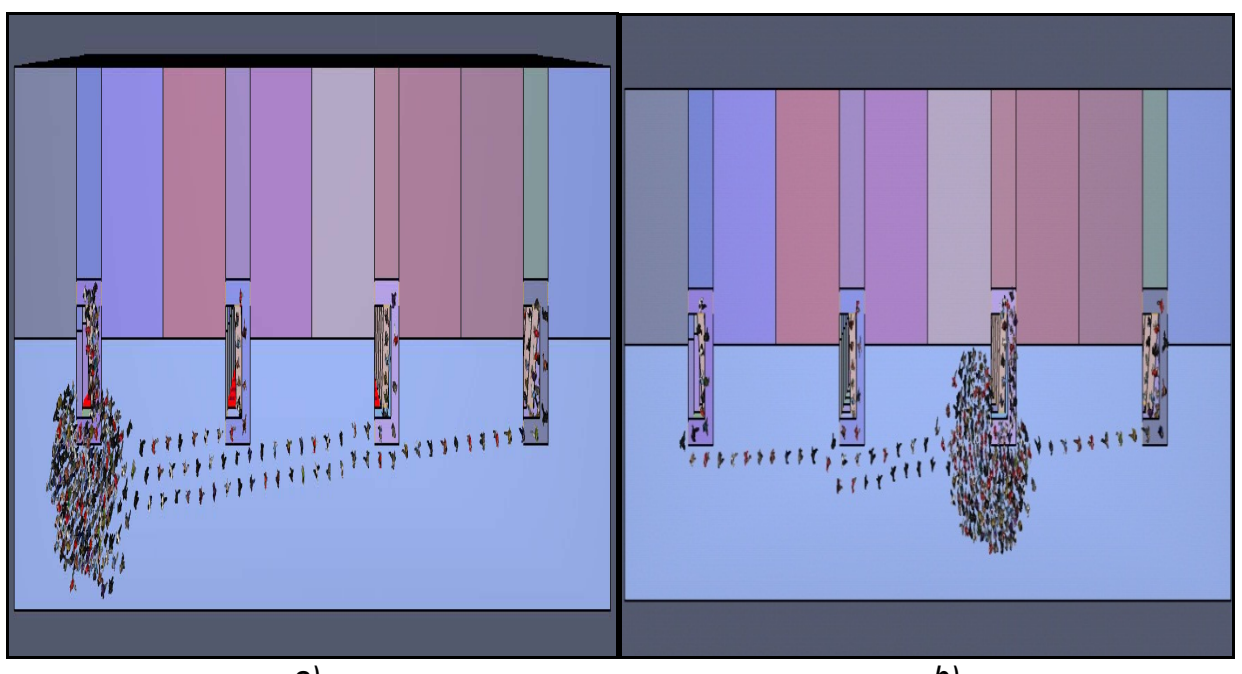

a)

b)

Figure 5 - Simulation scene for the fourth scenario where the fourth entrance/exit was opened while other entrances/exits were blocked, the elevators enabled and for the occupants' speeds of $0.75 \mathrm{~m} / \mathrm{s}$ (a) and a simulation scene for the fourth scenario where the second entrance/exit was opened while other entrances/exits were blocked, the elevators disabled and for the occupants' speeds of $1.75 \mathrm{~m} / \mathrm{s}(b)$

Puc. 5 - Имитационные сцены по четвертому сценарию, в котором четвертый вход/выход открыт, а остальные входы/выходы заблокированы и есть лифты, учитывая скорость жильцов: $0.75 \mathrm{M} / \mathrm{c}, 1 \mathrm{M} / \mathrm{c}, 1.25 \mathrm{M} / \mathrm{c}, 1.5 \mathrm{M} / \mathrm{c}$ u $1.75 \mathrm{~m} / \mathrm{c}$ (a) u имитационные сцены входы/выходы заблокированы и нет лифта, учитывая скорость жильцов: $0.75 \mathrm{M} / \mathrm{c}, 1 \mathrm{~m} / \mathrm{c}, 1.25 \mathrm{M} / \mathrm{c}, 1.5 \mathrm{M} / \mathrm{c}$ и $1.75 \mathrm{M} / \mathrm{c}$ (б)

Слика 5 - Симулационе сцене из четвртог сценарија где је четврти улаз/излаз отворен, док су остали улази/излази блокирани, са лифтовима и за брзине станара: 0,75 m/s, $1 \mathrm{~m} / \mathrm{s}, 1,25 \mathrm{~m} / \mathrm{s}, 1,5 \mathrm{~m} / \mathrm{s}$ и 1,75 m/s (a), и симулациони улази/излази блокирани, без лифртова, и за брзине станара: 0,75 m/s, $1 \mathrm{~m} / \mathrm{s}, 1,25$ $\mathrm{m} / \mathrm{s}, 1,5 \mathrm{~m} / \mathrm{s}$ u $1,75 \mathrm{~m} / \mathrm{s}$ (б)

The realized simulations have shown that times needed for an evacuation increased depending on the number of blocked entrances/exits and on whether the elevators were used or not. In reality, 
many of potential evacuation situations imply that elevators are not used and that was the main reason why every of four scenarios was analysed with enabled and disabled elevators. The factors that are important for elevators usage are, most frequently, the floor level where occupants are located and the acceptable waiting time. Experience and research have shown that higher locations in residential buildings are more likely to imply elevator usage than usage of ordinary or emergency stairs. It is also important to note that the acceptable waiting time increases according to the height of the floor level (Kinateder et al, 2014).

One very important factor that has a great influence on the evacuation time is panic. Panic causes fearful and chaotic behaviour which is, most frequently, demonstrated with an increase of speed of occupants. This speed increment results in crowds and jams that can be very unpredictable and very hard to solve. It means that the evacuation time can be significantly extended, which the simulation results proved.

It is also important to note that, in reality, every occupant has his/her own speed, while in the simulation all occupants had the same speed. Also, in reality, occupants' personal characteristics are very different and can affect the overall evacuation time and cause problems in the crowd (Kady \& Davis, 2009), (Jevtić, 2019b).

\section{Disccussion}

The usage of simulation software for simulating the evacuation in high-rise buildings is becoming more frequent and more extensive. The main reasons for that are: increase of safety in order to protect as many human lives as possible; increasingly frequent construction of high-rise buildings with a huge number of occupants; prediction and determination of optimal evacuation routes; prediction of potential occupants' behaviors, etc.

There are many residential buildings with and without emergency stairs. Very often, emergency stairs in residential buildings can be useless because of many reasons (fire, earthquake, smoke, jams, etc.) so that the only way to the exit is via ordinary stairs and elevators. As it has been noted before, the usage of elevators in many crises that need evacuation, such as fires or earthquakes, is not recommended. It does not mean that elevators should not be used at all but that there is a significant risk if they are used. This is a very important reason why evacuation simulations should be considered for cases with and without elevators usage. In some situations that can occur in high residential buildings or other objects with a significant presence of immobile 
persons, it is almost impossible to realize evacuation without elevators usage. The obtained results confirmed that the evacuation times were shorter in the cases where the elevators were enabled.

One very important factor in every evacuation is a so-called „human factor". This factor presents a very complex factor in sense of prediction and calculation. For example, people will not behave in the same way individually and in a group. During evacuation, parents will always tend to run towards their children which can significantly complicate the evacuation. Frequently, occupants in high residential buildings in disaster cases show apathetic behavior and non-acceptance of obvious facts. Taking ino account many important factors related to occupants in simulations (occupants physical dimensions, occupants' reduction factor, occupant comfort distance, occupants slow factor, speed, and many others) presents a very important task that demands knowledge from different sciences and disciplines.

The obtained simulation results were in the range of the obtained simulation results in similar cases. It is a very good and accurate way to compare the obtained simulation results with calculated results and experimental results, since it is not always possible to carry out such experiments in reality (Ding et al, 2017), (Poon, 1994), (Kasereka et al, 2018), (Rozo et al, 2019), (Xing \& Tang, 2012).

\section{Conclusion}

The results obtained in this paper have shown the maximum evacuation times in a building without emergency stairs with and without elevators usage. In reality, it is unlikely that, for example, all three entrances/exits are blocked, maybe only in case of a huge fire or a huge earthquake. However, it is very important to predict as many evacuation scenarios as possible and calculate adequate evacuation times.

Calculation of evacuation time and prediction of the best evacuation route presents a very complex and responsible task. Very often, it is almost impossible to predict every potential situation than can occur during evacuation. Because of that reason, usage of simulation software presents a very good, effective, cheap, and safe way for predicting potential evacuation situations in many different objects, which gives this topic great importance and motivation in order to save human lives and material properties. The main contributions of this paper are in its potential to determine optimal evacuation routes and calculate evacuation times in high buildings with or without emergency stairs, taking into consideration the influence of many different mentioned 
factors that can affect the evacuation progress and complete the evacuation epilogue.

Future investigations will relate to a simulation of evacuation with the presence of immobile persons of varying degrees of immobility, a simulation of evacuation via spiral staircases, a simulation of evacuation under different conditions, etc.

The usage of simulation software for the prediction and calculation of optimal evacuation routes can significantly improve the procedures and strategies of evacuation from some specific objects such as residential buildings.

\section{References}

Ding, N., Chen, T. \& Zhang, H. 2017. Simulation of high-rise building evacuation considering fatigue factor based on cellular automata: A case study in China. Building Simulation, 10(3), pp.407-418. Available at: https://doi.org/10.1007/s12273-016-0337-9.

-Fos Media. 2018. Požar ogromnih razmjera u centru Sao Paula, ima žrtava. Fos Media, 1 May [online]. Available at: https://fosmedia.me/svijet/globus/u-centru-sao-paula-gore-zgrade-ima-zrtavafoto (in Serbian) [Accessed: 21 August 2020].

Gershon, R.R.M., Magda, L.A., Riley, H.E.M. \& Sherman, M.F. 2011. The World Trade Center evacuation study: Factors associated with initiation and length of time for evacuation. Fire and materials, 36(5-6), pp.481-500. Available at: https://doi.org/10.1002/fam.1080.

Glavinić, P. \& Rašković Đ. 2016. Priručnik za pripremu kandidata za polaganje stručnog ispita iz oblasti zaštite od požara. Belgrade: Meritus tim (in Serbian). ISBN: 978-86-917589-91.

Hartley-Parkinson, R. 2019. Grenfell Tower fire report finds far more people could have survived disaster. Metro, 29 October [online]. Available at: https://metro.co.uk/2019/10/29/london-fire-brigade-serious-shortcomingsresponse-grenfell-disaster-11001429/ [Accessed: 21 August 2020].

Jevtić, R.B. 2016. Simulation of evacuation situations in order to protect human lives and material property. NBP. Nauka, bezbednost, policija, 21(2), pp.35-48. Available at: https://doi.org/10.5937/nbp1602035J.

Jevtić, R.B. 2018. Fire and evacuation in high residential buildings. Facta Universitatis, Series: Working and living environmental protection, 15(2), pp.123134. Available at: https://doi.org/10.22190/FUWLEP1802123J.

Jevtić, R.B. 2019a. Simulation of fire as a form of safety and protection of human lives and material assets. Facta Universitatis, Series: Working and living environmental protection, 16(3), pp.171-184. Available at: https://doi.org/10.22190/FUWLEP1903171J. 
Jevtić, R.B. 2019b. Sanitary objects evacuation with presence of immobile occupants. Zdravstvena zaštita, 48(1), pp.61-68. Available at: https://doi.org/10.5937/ZZ1901061J.

Kady, R.A. \& Davis, J. 2009. The effect of occupant characteristics on crawling speed in evacuation. Fire Safety Journal, 44(4), pp.451-457. Available at: https://doi.org/10.1016/j.firesaf.2008.09.010.

Kasereka, S., Kasoro, N., Kyamakya, K., Doungmo Goufo, E-F., Chokki, A.P. \& Yengo, M.V. 2018. Agent-Based Modelling and Simulation for evacuation of people from a building in case of fire. Procedia Computer Science, 130, pp.10-17. Available at: https://doi.org/10.1016/j.procs.2018.04.006.

Kinateder, M.T., Omori, H. \& Kuligowski, E.D. 2014. The Use of Elevators for Evacuation in Fire Emergencies in International Buildings. Gaithersburg, Maryland: National Institute of Standards and Technology. Available at: https://doi.org/10.6028/NIST.TN.1825.

Mumović, N. 2019. Evakuacija iz stambenih objekata u vanrednim situacijama izazvanim požarima. MA thesis. Belgrade: University of Belgrade Faculty of Security Studies (in Serbian).

Pauls, J.L. 2005. Evacuation of Large High-Rise Buildings: Reassessing Procedures and Exit Stairway Requirements in Codes and Standards. In: Proceedings of the 7th Conference of the Council of Tall Buildings and Urban Habitat, New York, USA, pp.16-19.

Poon, L.S. 1994. EvacSim: A Simulation Model of Occupants with Behavioural Attributes in Emergency Evacuation of High-Rise Building Fires. In: Kashiwagi, T. (Ed.) Fire Safety Science-Proceedings of the Fourth International Symposium, Ottawa, Ontario, Canada, pp.681-692, July 13-17 [online]. Available at: https://iafss.org/publications/fss/4/view [Accessed: 21 August 2020].

Ronchi, E. \& Nilsson, D. 2013. Fire evacuation in high-rise buildings: a review of human behaviour and modelling research. Fire Science Reviews, 2(art.number:7). Available at: https://doi.org/10.1186/2193-0414-2-7.

Rozo, K.R., Arellana, J., Santander-Mercado, A. \& Jubiz-Diaz, M. 2019. Modelling building emergency evacuation plans considering the dynamic behaviour of pedestrians using agent-based simulation. Safety Science, 113, pp.276-284. Available at: https://doi.org/10.1016/j.ssci.2018.11.028.

-Thunderhead. 2014. Pathfinder User Manual. Manhattan, KS, USA: Thunderhead Engineering [online]. Available at: https://www.thunderheadeng.com/wpcontent/uploads/downloads/2014/10/users_guide.pdf [Accessed: 21 August 2020]

Xing, Z. \& Tang, Y. 2012. Simulation of Fire and Evacuation in High-Rise Building. Procedia Engineering, $\underline{45}$, pp.705-709. Available at: https://doi.org/10.1016/j.proeng.2012.08.227. 
ПОЖАРНАЯ БЕЗОПАСНОСТЬ ЖИЛЫХ ЗДАНИЙ - ЭВАКУАЦИЯ ИЗ ЖИЛЫХ ЗДАНИЙ БЕЗ ПОЖАРНОЙ ЛЕСТНИЦЫ

Радое Б. Евтич

Электротехнический техникум «Никола Тесла»,

г. Ниш, Республика Сербия

\section{РУБРИКА ГРНТИ: 67.00 .00 СТРОИТЕЛЬСТВО. АРХИТЕКТУРА}

67.53.33 Противопожарная защита зданий и сооружений

ВИД СТАТЬИ: оригинальная научная статья

Резюме:

Введение/цель: Безопасность в высотных жилых зданиях является очень важной и всегда актуальной задачей. В случае возникновения непредвиденных $и$ опасных происшествий, жильцов необходимо эвакуировать. Пожары, землетрясения и терроризм - лишь некоторые из таких ситуаций. Скорость эвакуации из высотных жилых зданий зависит от множества различных фракторов. Эвакуация во многом усложняется, если в зданиях нет пожарных лестниц.

Методы: В данной статье применялся метод моделирования. На основе реального объекта - жилого здания была создана соответствующая имитационная модель с помощью соответствующей имитационной программы.

Результаты: Результаты исследования показали, что из четырех сценариев наиболее быстрая эвакуация была при скорости жильцов 1,75 м / с. В первых двух сценариях не было выявлено ни одного затора, в отличие от третьего и четвертого сценариев; в третьем сценарии скорости жильцов составляли 0,75 м / с и 1,25 м / с, а в четвертом сценарии смоделированные скорости жильцов составляли от 0,75 м / с до $1,75 \mathrm{M} / \mathrm{C}$.

Выводы: Применение соответствующего программного обеспечения для моделирования позволяет быстро, точно, безопасно и дешево рассчитать время эвакуации и может значительно улучшить процесс и стратецию эвакуации.

Ключевые слова: эвакуация, здание, люди, моделирование.

БЕЗБЕДНОСТ У СТАМБЕНИМ ЗГРАДАМА - ЕВАКУАЦИЈА СТАМБЕНЕ ЗГРАДЕ БЕЗ ПОЖАРНИХ СТЕПЕНИЦА

Радоје Б. Јевтић

Електротехничка школа „Никола Тесла”, Ниш, Република Србија

ОБЛАСТ: заштита од пожара

ВРСТА ЧЛАНКА: оригинални научни рад 


\section{Сажетак:}

Уводциљ: Безбедност у високим стамбеним зградама представља веома важан задатак. У случају неке непредвиђене и опасне појаве, станари тих зграда морају бити евакуисани. Пожар, земљотрес и терористичке акције само су неке од таквих ситуација. Брзина евакуације из високе стамбене зграде зависи од много различитих фактора. Задатак евакуације је посебно тежак и компликован уколико зграда нема пожарне степенице.

Mетоде: У овом раду коришћена је метода моделовања. На основу реалног објекта - стамбене зграде, реализован је одговарајући симулациони модел у одговарајућем симулационом софттверу.

Резултати: Резултати овог рада показали су да је најбржа евакуација остварена за сваки од четири сценарија при брзини станара од $1,75 \mathrm{~m} / \mathrm{s}$, с тим да за прва два сценарија нису забележени застоји, али су за трећи и четврти сценарио застоји уочени.Наиме, у трећем сценарију до застоја је дошло при брзини станара од $0,75 \mathrm{~m} / \mathrm{s}$ и 1,25 m/s, а у четвртом сценарију за све симулиране брзине станара од 0,75 m/s до 1,75 m/s.

Закључак: Употреба одговарајућег симулационог софтвера омогућава брзо, прецизно, безбедно и јефртино израчунавање евакуационих времена и може знатно побољщати евакуационе процедуре и евакуациону стратегију.

Кључне речи: евакуација, зграда, станари, симулација.

Paper received on / Дата получения работы / Датум пријема чланка: 28.08.2020. Manuscript corrections submitted on / Дата получения исправленной версии работы / Датум достављања исправки рукописа: 02.11.2020.

Paper accepted for publishing on / Дата окончательного согласования работы / Датум коначног прихватања чланка за објављивање: 04.11.2020.

(c) 2021 The Author. Published by Vojnotehnički glasnik / Military Technical Courier (www.vtg.mod.gov.rs, втг.мо.упр.срб). This article is an open access article distributed under the terms and conditions of the Creative Commons Attribution license (http://creativecommons.org/licenses/by/3.0/rs/)

( 2021 Автор. Опубликовано в «Военно-технический вестник / Vojnotehnički glasnik / Military Technical Courier» (www.vtg.mod.gov.rs, втг.мо.упр.срб). Данная статья в открытом доступе и распространяется в соответствии с лицензией «Creative Commons» (http://creativecommons.org/licenses/by/3.0/rs/).

(c) 2021 Аутор. Објавио Војнотехнички гласник / Vojnotehnički glasnik / Military Technical Courier (www.vtg.mod.gov.rs, втг.мо.упр.срб). Ово је чланак отвореног приступа и дистрибуира се у складу са Creative Commons licencom (http://creativecommons.org/licenses/by/3.0/rs/). 